\title{
Secondary Metabolites with Anti-Inflammatory Activities from One Actinobacteria Amycolatopsis taiwanensis
}

\author{
Yung-Shun Su ${ }^{1,2}$, Ming-Der Wu ${ }^{3}$, Jih-Jung Chen ${ }^{4,5, * \mathbb{D}}$, Ming-Jen Cheng ${ }^{3} * \mathbb{D}$, Yueh-Hsiung Kuo ${ }^{6,7,8}$, \\ Chee-Yin Chai ${ }^{1,9}$ and Aij-Lie Kwan 1,10,11,*
}

1 Graduate Institute of Medicine, College of Medicine, Kaohsiung Medical University (KMU), Kaohsiung 807, Taiwan; mariussu@gmail.com (Y.-S.S.); cychai@kmu.edu.tw (C.-Y.C.)

2 Department of Dermatology, Kaohsiung Medical University Chung-Ho Memorial Hospital, Kaohsiung 807, Taiwan

3 Bioresource Collection and Research Center (BCRC), Food Industry Research and Development Institute (FIRDI), Hsinchu 300, Taiwan; wmd@firdi.org.tw

4 Department of Pharmacy, School of Pharmaceutical Sciences, National Yang Ming Chiao Tung University (NYCU), Taipei 112, Taiwan

5 Department of Medical Research, China Medical University Hospital, Taichung 404, Taiwan

6 Department of Chemistry, National Taiwan University, Taipei 106, Taiwan; yhkuo800@gmail.com

7 Department of Biotechnology, Asia University, Taichung 413, Taiwan

8 Department of Chinese Pharmaceutical Sciences and Chinese Medicine Resources, College of Pharmacy, China Medical University, Taichung 404, Taiwan

9 Department of Pathology, Kaohsiung Medical University Chung-Ho Memorial Hospital, Kaohsiung 807, Taiwan

10 Ph.D. Program in Environmental and Occupational Medicine, College of Medicine, Kaohsiung Medical University and National Health Research Institutes, Kaohsiung 807, Taiwan

check for

updates

Citation: Su, Y.-S.; Wu, M.-D.; Chen, J.-J.; Cheng, M.-J.; Kuo, Y.-H.; Chai, C.-Y.; Kwan, A.-L. Secondary Metabolites with Anti-Inflammatory Activities from One Actinobacteria Amycolatopsis taiwanensis. Molecules 2021, 26, 5765. https://doi.org/ $10.3390 /$ molecules26195765

Academic Editor: Bruno Botta

Received: 13 August 2021

Accepted: 10 September 2021

Published: 23 September 2021

Publisher's Note: MDPI stays neutral with regard to jurisdictional claims in published maps and institutional affiliations.

Copyright: (c) 2021 by the authors. Licensee MDPI, Basel, Switzerland. This article is an open access article distributed under the terms and conditions of the Creative Commons Attribution (CC BY) license (https:/ / creativecommons.org/licenses/by/ $4.0 /)$.
11 Department of Neurosurgery, Kaohsiung Medical University Chung-Ho Memorial Hospital, Kaohsiung 807, Taiwan

* Correspondence: jjungchen@nycu.edu.tw (J.-J.C.); chengfirdi@gmail.com (M.-J.C.); aijliekw@kmu.edu.tw (A.-L.K.)

Abstract: Phytochemical investigation and chromatographic separation of extracts from one new actinobacteria strain Amycolatopsis taiwanensis that was isolated from soil of Yilan township, in the north of Taiwan, led to the isolation of nine new compounds, amycolataiwanensins A-I (1-9, resp.), and one new natural product, namely amycolataiwanensin J (10). The structures of the new compounds were unambiguously elucidated on the basis of extensive spectroscopic-data analysis (1D- and 2DNMR, MS, and UV) and comparison with literature data. The effect of some isolates on the inhibition of NO production in lipopolysaccharide-activated RAW 264.7 murine macrophages was evaluated. Of the isolates, 3, 5, 7 and 8 exhibited potent anti-NO production activity, with $I C_{50}$ values of 17.52, $12.31,17.81$ and $13.32 \mu \mathrm{M}$, respectively, compared to that of quercetin, an iNOS inhibitor with an $\mathrm{IC}_{50}$ value of $35.94 \mu \mathrm{M}$. This is the first report on indole metabolite from the genus Amycolatopsis.

Keywords: Amycolatopsis taiwanensis; Pseudonocardiaceae; actinobacteria; secondary metabolites; NO inhibition

\section{Introduction}

Actinobacteria are well known as an outstanding and fascinating source of commercially valuable bioactive compounds, particularly antibiotics. Almost a half of the known microbial bioactive secondary metabolites are derived from actinomycetes, of which more than $70 \%$ were obtained from the genus Streptomyces. However, the active ingredients of many new Taiwanese actinobacteria and their mechanisms of actions are still unknown. It is necessary to study on the active compounds by scientific methods from these rare actinobacteria. Actinobacteria are widely distributed in nature. They seem to have unlimited ability to produce secondary metabolites with multiple chemical structures and 
biological activities, so they have a place in the pharmaceutical industry [1-5]. They are Gram-positive, free-living saprophytic bacteria that exist in soil, water and colonizing plants. The residents of actinobacteria have been identified as one of the main groups of soil populations [4], may vary depending on the type of soil.

Based on our long-term plan for the collection and identification of new species of native actinobacteria in Taiwan, we isolated several new strains from Taiwan soil. A strain named 0345M-7T was isolated from soil sediment samples in Yilan County, Taiwan. It has a unique morphology after observation through an electron microscope [4].

This strain was determined to be Amycolatopsis taiwanensis, (Family: Pseudonocardiaceae) based on their phenotypic and genotypic data [5]. The isolate displayed substrate mycelia, upon which were borne short spore chains. The spore chains were composed of non-motile, smooth-surfaced, oval spores. The genus Amycolatopsis (Lechevalier et al. 1986) contains more than 70 species and its main habitat is soil. Strains of this genus can produce a variety of important antibiotics and secondary metabolites, such as balimycin, dethymicin, rifamycin, vancomycin, and can be used for drug-resistant Staphylococcus, organ transplantation, leprosy, tuberculosis, etc. Although the strains of the genus Amycolatopsis have been researched and developed very early and many times, A. taiwanensis is a new strain isolated from Taiwan, and no relevant research has been carried out. It has the potential to discover new compounds. According to the literature search, it was found that 159 compounds of the genus Amycolatopsis were reported from 8 known species and 18 unknown species [6]. These secondary metabolites are mainly divided into polyphenols, linear polyketides, macrolides, macrolides, thiazolyl peptides, cyclic peptides, glycopeptides, amides and amino derivatives, glycoside derivatives, and enediyne derivatives, and sesquiterpenes. At the same time, they mainly exhibit unique antibacterial, anti-cancer, anti-oxidant, anti-hyperglycemic and enzyme inhibitory activities.

In the course of our search for potential diverse secondary metabolites from natural microbial sources, and to further understanding of the minor metabolites of the genus Amycolatopsis, we examined the EtOAc extract of A. taiwanensis, which showed rich metabolites according to the HPLC fingerprint analysis and inhibitory activity on LPS-induced NO release in RAW 264.7 murine macrophages, as determined by our primary screening. Investigation of the bioactive metabolites of the active EtOAc extract from the microbe $A$. taiwanensis, fermented by liquid fermentation was investigated. The metabolites investigation guided by the HPLC profile analysis and ${ }^{1} \mathrm{H}-\mathrm{NMR}$ spectrum prescreening led to the isolation of nine new metabolites, amycolataiwanensins A-I (1-9), and one metabolite isolated for the first time from nature sources, amycolataiwanensin J (10) (Figure 1 and the Supplementary part). The structures of these isolates were established by means of spectral experiments. The isolation, structural elucidation, inhibitory effects of some isolates on nitric oxide (NO) production by RAW264.7 macrophages are described herein. 

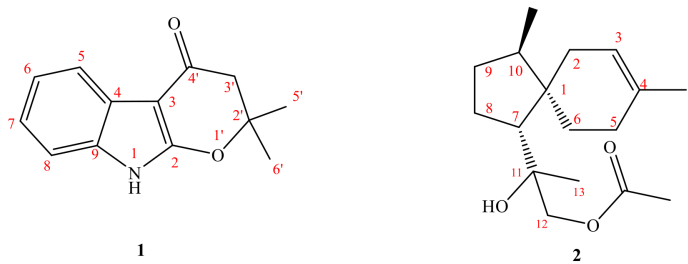<smiles>CC(C)c1cc2c(c(O)c1O)[C@@]1(C)CCC(=O)C(C)(C)C1[C@H](O)[C@H]2O</smiles><smiles>CC(C)C1=C(O)C(=O)C2=C(CCC3C(C)(C)[C@H](O)CC[C@@]23C)C1=O</smiles><smiles>CC(O)c1ccc2c(c1)CC[C@H]1C(C)(C)CCC[C@@]21C</smiles><smiles>CC1(C)CC[C@H]2C(=CC1=O)CC[C@H]1C(C)(C)CCC[C@]12C</smiles>

6<smiles>COc1cc(CCCOC(C)=O)cc(OC)c1O</smiles><smiles>CC(C)=CCCC1(C)C=Cc2cc(-c3ccc(O)cc3)cc(O)c2O1</smiles><smiles>CC1(C)CCc2cc(-c3ccc(O)cc3)cc(O)c2O1</smiles>

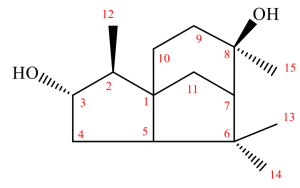

Figure 1. Compounds 1-10, isolated from Amycolatopsis taiwanensis.

\section{Results and Discussion}

Compound 1 was isolated as oil. The HR-EI-MS spectrum gave a molecule ion [M] $]^{+}$ at $m / z 215.0948$, consistent with a molecular formula of $\mathrm{C}_{13} \mathrm{H}_{13} \mathrm{NO}_{2}$. UV spectrum showed maximum absorption at 241 (4.20), 264 (4.09) and 310 (3.98) nm, indicating the presence of an indole skeleton [7]. Its IR spectrum revealed NH absorption at $3320 \mathrm{~cm}^{-1}$. Analysis of the ${ }^{1} \mathrm{H}$ NMR spectrum of $\mathbf{1}$ revealed four typical mutually coupling aromatic protons of indole alkaloid at $\delta_{\mathrm{H}} 7.08(1 \mathrm{H}, \mathrm{td}, J=8.0,1.2 \mathrm{~Hz}, \mathrm{H}-7), 7.11(1 \mathrm{H}, \mathrm{td}, J=8.0,1.2 \mathrm{~Hz}$, $\mathrm{H}-6), 7.26(1 \mathrm{H}, \mathrm{dd}, J=8.0,1.2 \mathrm{~Hz}, \mathrm{H}-8), 7.84(1 \mathrm{H}, \mathrm{dd}, J=8.0,1.2 \mathrm{~Hz}, \mathrm{H}-5)$ and one NH group at $\delta_{\mathrm{H}} 7.66\left(1 \mathrm{H}, \mathrm{br} \mathrm{s}\right.$, exchangeable with $\left.\mathrm{D}_{2} \mathrm{O}\right)$. According to the molecular formula, the degree of unsaturation can be calculated to be 8 . After deducting the two rings and four double bonds of indole, there are also 2 remains. In addition to the carbon spectrum, there is a conjugated carbonyl signal at $\delta_{C}$ 183.99. It is speculated that the branched chain forms a ring ( $\mathrm{C}$ ring). It can be confirmed from the fact that the methylene signal on the carbonyl $\alpha$ carbon is $\delta_{\mathrm{H}} 2.63(2 \mathrm{H}, \mathrm{s})$ in a lower magnetic field. In addition, the two carbon absorption signals on the pyrrole ring of indole, a particularly low magnetic field 
and a high magnetic field, are presumably affected by the electronic resonance of the carbonyl group. Therefore, one end of the branch is connected to a carbon with a higher magnetic field $\left(\delta_{C} 95.15\right)$ through a carbonyl carbon. The carbon with a lower magnetic field $\left(\delta_{C} 160.87\right)$ should also be connected to an oxygen and be affected by the carbonyl group to achieve such a low magnetic field. Observing the carbon spectrum, there is also a quaternary carbon connected to oxygen. It is obvious that the other end of the branch chain is connected to indole with this oxygen. There is also a single peak integrated into $6 \mathrm{H}$ in the ${ }^{1} \mathrm{H}$ NMR, $\delta_{\mathrm{H}} 1.57\left(6 \mathrm{H}, \mathrm{s}, \mathrm{CH}_{3}-5^{\prime}, 6^{\prime}\right)$, which is presumed to be two methyl groups with the same signal, and the position is on the quaternary carbon $\left(\delta_{C} 86.2\right)$ connected to oxygen. The HMBC ${ }^{3} \mathrm{~J}$-correlations (Figure 2) from $\delta_{\mathrm{H}} 2.63\left(\mathrm{CH}_{2}-3^{\prime}\right)$ to $\delta_{\mathrm{C}} 95.2(\mathrm{C}-3)$ and one weak ${ }^{4} \mathrm{~J}$-correlations $\delta_{\mathrm{H}} 1.57\left(6 \mathrm{H}, \mathrm{s}, \mathrm{CH}_{3}-5^{\prime}, 6^{\prime}\right)$ to $\delta_{\mathrm{C}} 160.9(\mathrm{C}-2)$, verify the junction of the 2,2-dimethyldihydropyrano ring to the indole moiety at $\mathrm{C}-2$, and 3 . The other key correlations of HMBC are illustrated in Figure 2. Based on the above data, the structure of 1, named amycolataiwanensin A, was elucidated as 2,2-dimethyl-2,3-dihydropyrano[2,3b]indol-4(9H)-one, which was further confirmed by ${ }^{13} \mathrm{C}$ NMR, COSY, NOESY (Figure 3), HSQC and HMBC (Figure 2) experiments.

Compound 2, isolated as gum, showed a dehydrated molecular ion $\left[\mathrm{M}-\mathrm{H}_{2} \mathrm{O}\right]^{+}$peak at $m / z 262.1933$ for $\mathrm{C}_{17} \mathrm{H}_{26} \mathrm{O}_{2}$, corresponding to four indexes of hydrogen deficiency (IHD). The IR spectrum of 2 displayed an absorption for an $\mathrm{OH}$ group $\left(3500 \mathrm{~cm}^{-1}\right)$ and a $\mathrm{C}=\mathrm{O}$ group (1740 $\left.\mathrm{cm}^{-1}\right)$. The ${ }^{1} \mathrm{H}$ - and ${ }^{13} \mathrm{C}-\mathrm{NMR}, \mathrm{COSY}, \mathrm{HMBC}$, and NOESY data (Figure 3 ) established the structure of 2 as 12-acetoxy-11-hydroxyacora-3-ene.

The ${ }^{1} \mathrm{H}-\mathrm{NMR}$ spectrum exhibited signals for a trisubstituted olefinic proton $\left[\delta_{\mathrm{H}} 5.30\right.$ (br s, H-3)], an oxymethylene at $\delta_{\mathrm{H}} 3.93 / 4.05$ (each $\mathrm{d}, J=11.0 \mathrm{~Hz}, \mathrm{CH}_{2}-12$ ), and the four methyl groups include three singlet methyl groups $\delta_{\mathrm{H}} 1.24$ (s), 1.58 (s), 2.08 (s) and a doublet methyl group at $\delta_{\mathrm{H}} 0.82\left(\mathrm{~d}, \mathrm{CH}_{3}-14\right)$. From the carbon spectrum $\left({ }^{13} \mathrm{C}-\mathrm{NMR}\right)$ and DEPT, because of the appearance of one quaternary carbon at $\delta_{C} 171.2$ (ester) and one primary carbon at $\delta_{C} 20.9\left(\mathrm{CH}_{3}\right)$, it can be seen that there is an acetoxy group. In addition, there are two quaternary carbons $\delta_{C} 44.70$ and 74.85 (of which $\delta_{C} 74.35$ is the oxygen-containing quaternary carbon). Calculating the degree of unsaturation, subtracting a double bond and a carbonyl group, there is 2 left, so it can be determined that there are two more rings in this structure. According to the above characteristic spectrum information and reference data, [8] it can be known that the NMR information of this structure are very similar to the spectrum of a known compound 12-acetoxy-11-hydroxyacora-4-ene, so it is inferred that this compound It is also belonged to acorane backbone compound. According to the signal of HMBC, the structure is similar to the known compound 12-acetoxy-11-hydroxyacora4-ene, [8] while the signal of NOESY explains the difference in stereo orientation: (1) The H-2 has NOE correlation signals with H-3 and H-14 in compound 2. (2) In the similar compound 12-acetoxy-11-hydroxyacora-4-ene, its H-6 has NOE correlation signal with $\mathrm{H}-13$ and H-5. Therefore, the structure and steric orientation of compound 2 were proved. The above spectroscopic data proves that the structure is correct, and this new compound is named amycolataiwanensin B.

Compound 3 had the dehydrated molecular ion peak $\left[\mathrm{M}-\mathrm{H}_{2} \mathrm{O}\right]^{+}$at $m / z 330.1831$ (HR-EI-MS), as analyzed for $\mathrm{C}_{20} \mathrm{H}_{28} \mathrm{O}_{5}$. The IR spectrum of 3 exhibited the presence of an $\mathrm{OH}$ group at $3400 \mathrm{~cm}^{-1}$ and a CO moiety at $1695 \mathrm{~cm}^{-1}$. The UV absorptions $\left(\lambda_{\max }\right.$ 229.0 and $256.0 \mathrm{~nm}$ ) confirmed an aromatic system. Seven IHD were determined from the molecular formula, ${ }^{13} \mathrm{C}-\mathrm{NMR}$ spectrum, and DEPT. Further spectral data (Tables 1 and 2) and comparison with reference compounds [9] established the structure of 3 as $6 \alpha, 7 \alpha, 11$ trihydroxy-3-oxoferrugiol. The ${ }^{1} \mathrm{H}-\mathrm{NMR}$ spectrum of 3 indicated the presence of an $\mathrm{iPr}$ group $\left(\delta_{\mathrm{H}} 1.27(\mathrm{~d})\right.$ and $1.28(\mathrm{~d})$, and 2.99 (sep)) attached to the benzene ring, two phenol groups $(\delta 4.85(\mathrm{~s}), 5.81(\mathrm{~s}))$, another three Me groups $\left(\delta_{\mathrm{H}} 1.21(\mathrm{~s}), 1.33(\mathrm{~s})\right.$, and $\left.1.45(\mathrm{~s})\right)$ attached to a quaternary carbon, two OCH groups $\left(\delta_{\mathrm{H}} 4.96(\mathrm{~d}, 5.0)\right.$ and $\left.4.44(\mathrm{dd}, 11.5,5.0)\right)$, the signal of five substituted benzene ring at 6.81 (s, H-14). According to the ${ }^{13} \mathrm{C}-\mathrm{NMR}$ and DEPT, the benzene ring $\delta_{C} 125.33,130.44,139.96,142.42,132.91$ and 119.70 composed of 6 olefinic carbons; there is a carbonyl group at $\delta_{C} 219.66$, and two oxygen-containing tertiary 
carbons at $\delta_{C} 68.3(\mathrm{C}-7)$, and 74.3 (C-6). Based on the above information and combining the above characteristic spectra data, the compound 3 with the abietane skeleton can be identified. The $\mathrm{H}-1 \beta$ at $\delta_{\mathrm{H}} 3.03(\mathrm{~m})$ is the result of the displacement of the low magnetic field due to the influence of the hydroxyl group on C-11. In order to determine the structure and the position of each functional group, continue with two-dimensional nuclear magnetic resonance spectroscopy (HSQC, HMBC) and NOESY experiments. According to the key information of HMBC: (1) H-18 and H-19 are correlated to $\delta_{C} 219.66$, so it is determined that the carbonyl group is located at the position of C-3; (2) H-14 is only related to $\delta_{C} 68.26$, so the two tertiary hydroxyl carbons can be distinguished. (3) Because $\delta_{\mathrm{H}} 5.81(\mathrm{~s}, \mathrm{OH}-12)$ is correlated to $C-12$, the two phenols can be distinguished and make sure that $\delta_{\mathrm{H}} 5.81$ (s) is connected to C-12. According to the signal from NOESY: (1) H-5 is connected with H-1 $\alpha$ and $\mathrm{H}-18$ respectively; (2) $\mathrm{H}-6$ is connected with $\mathrm{H}-19$ and $\mathrm{H}-20$, so it is determined to be in the axial position; (3) $\mathrm{H}-7$ is related to $\mathrm{H}-6 \beta$ and $\mathrm{H}-14$, and by its coupling constant $(J=5.0 \mathrm{~Hz})$, it can also be determined that it is in the equatorial position. Compound 3 is a previously undescribed diterpene and was named amycolataiwanensin C.

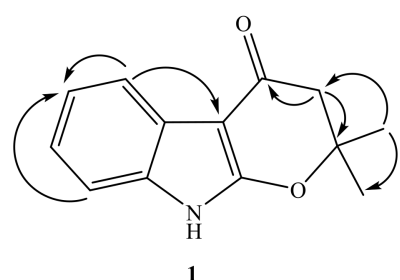

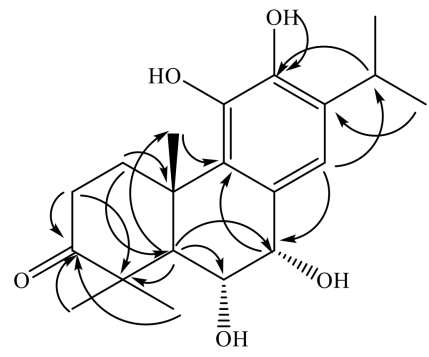

3

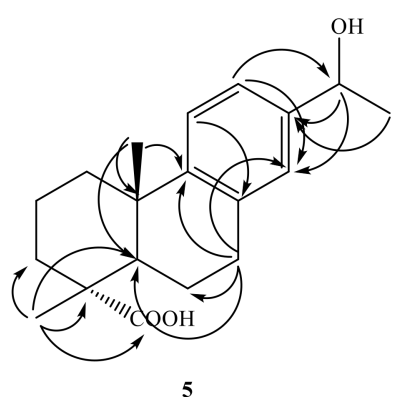

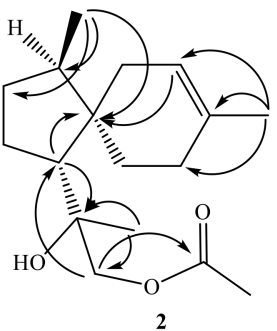

2
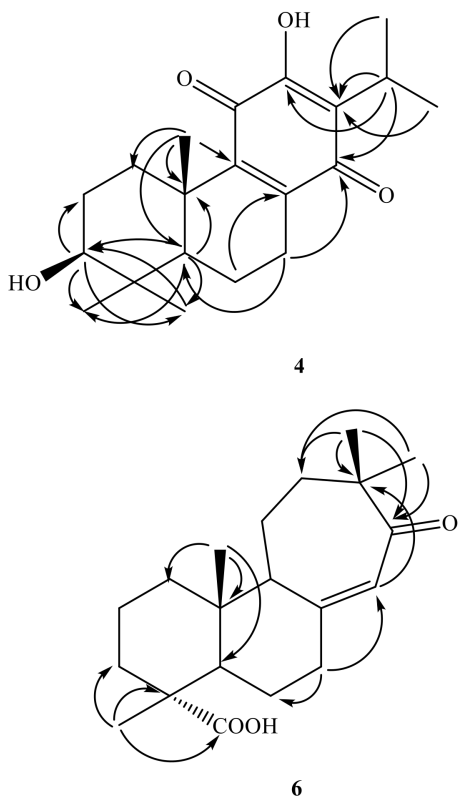

Figure 2. Cont. 

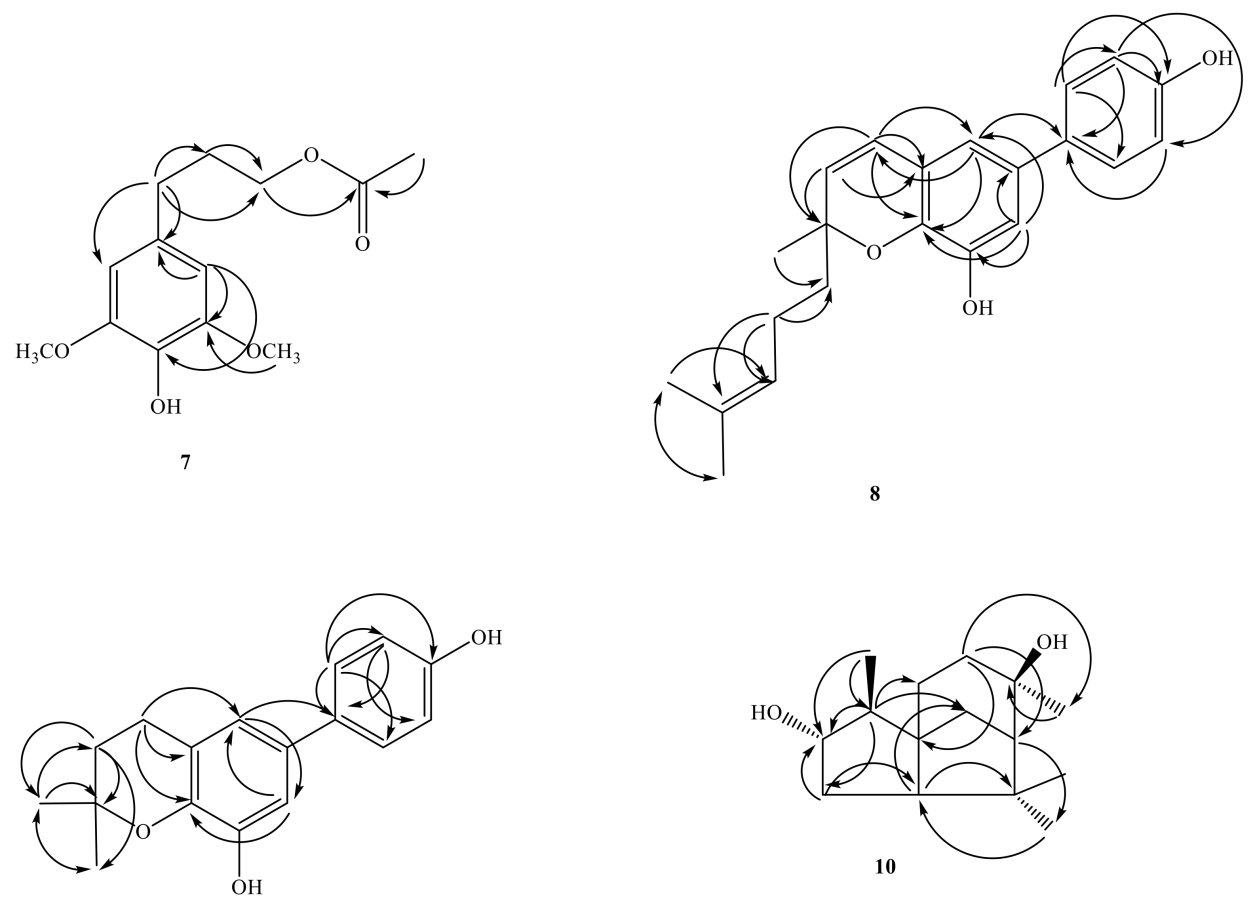

Figure 2. Key HMBC $(\rightarrow)$ correlations of 1-10.
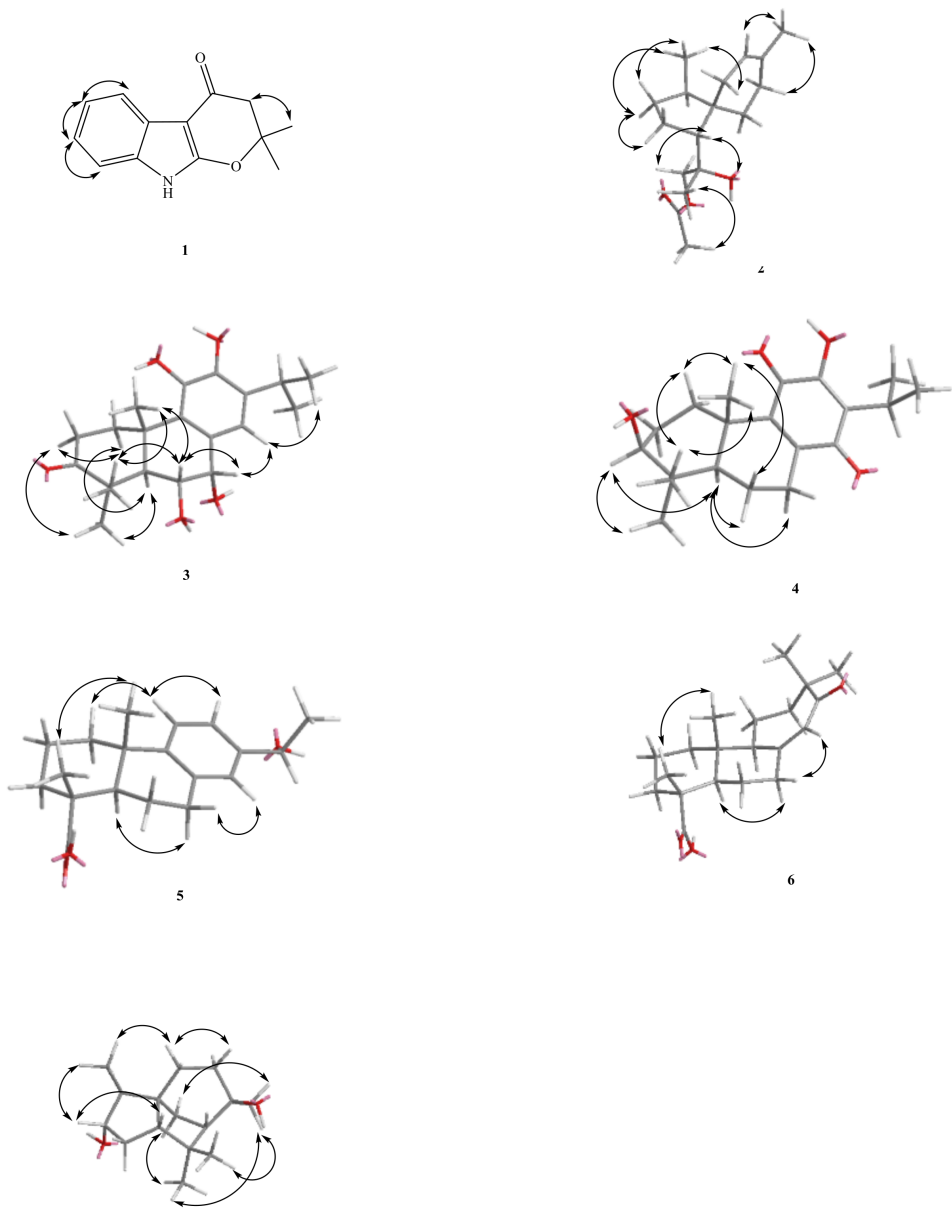

Figure 3. Major NOESY $(\leftrightarrow)$ contacts of $\mathbf{1 - 6}$ and $\mathbf{1 0}$. 
Table 1. ${ }^{1} \mathrm{H}$ NMR Data for Compounds $\mathbf{1 - 1 0}$ in $\mathrm{CDCl}_{3}\left(\delta\right.$ in ppm, $J$ in $\mathrm{Hz}, 500 \mathrm{MHz}$ in $\left.\mathrm{CDCl}_{3}\right)$.

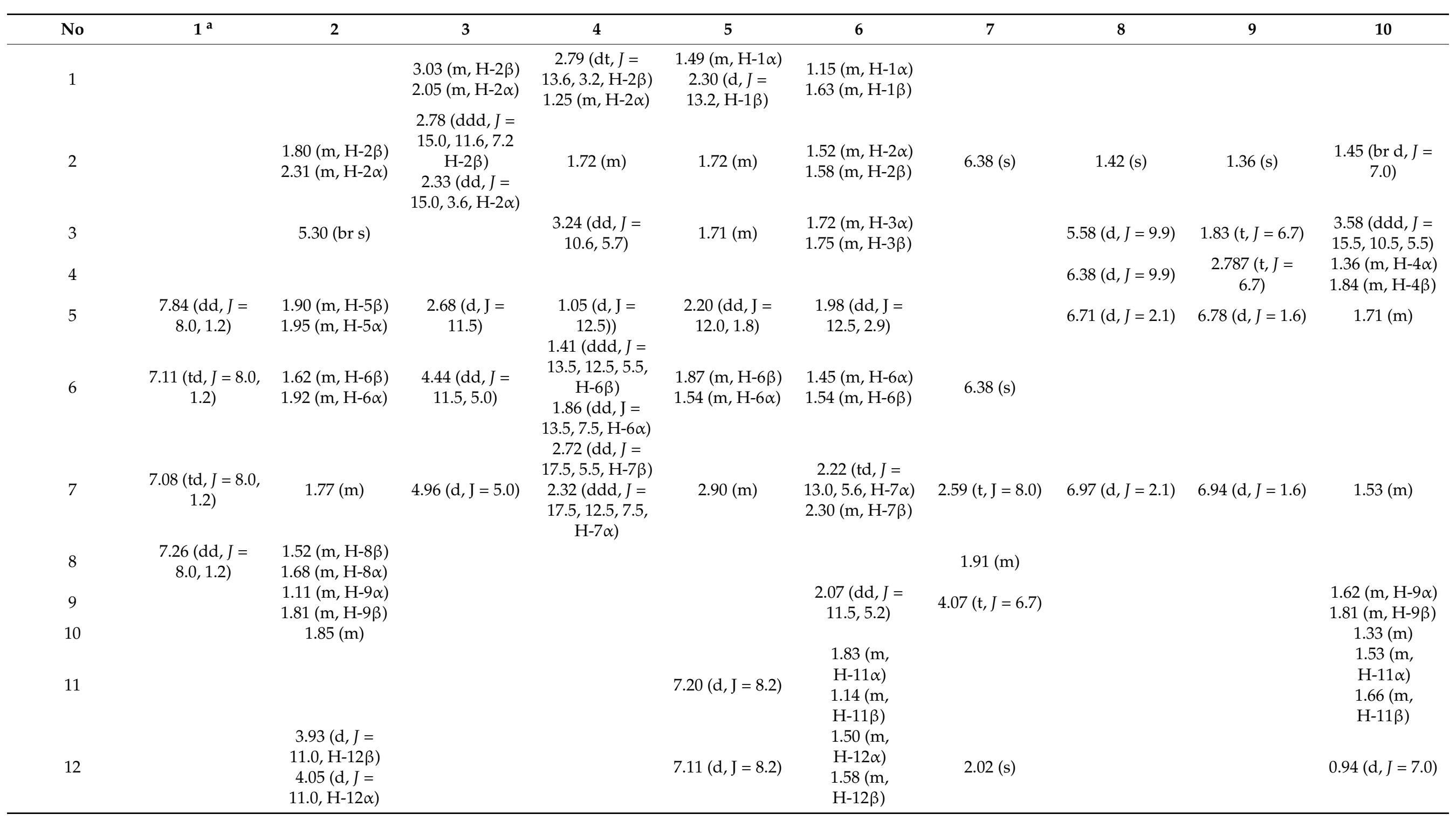


Table 1. Cont.

\begin{tabular}{|c|c|c|c|c|c|c|c|c|c|c|}
\hline No & $1^{a}$ & 2 & 3 & 4 & 5 & 6 & 7 & 8 & 9 & 10 \\
\hline 13 & & $1.24(\mathrm{~s})$ & & & & & & & & $1.32(\mathrm{~s})$ \\
\hline 14 & & $0.82(\mathrm{~d}, J=7.0)$ & $6.81(\mathrm{~s})$ & & 7.01 (br s) & 5.82 (br s) & & & & $1.00(\mathrm{~s})$ \\
\hline 15 & & $1.58(\mathrm{~s})$ & $\begin{array}{c}2.99 \text { (sept, } \mathrm{J}= \\
7.0)\end{array}$ & $\begin{array}{c}3.12 \text { (sept, } \mathrm{J}= \\
7.0)\end{array}$ & $\begin{array}{c}4.80(\mathrm{q}, . J= \\
6.5)\end{array}$ & & & & & $1.23(\mathrm{~s})$ \\
\hline 16 & & & $1.27(\mathrm{~d}, J=7.0)$ & $1.19(\mathrm{~d}, J=7.0)$ & & $1.13(\mathrm{~s})$ & & & & \\
\hline 17 & & $2.08(\mathrm{~s})$ & $1.28(\mathrm{~d}, J=7.0)$ & $1.18(\mathrm{~d}, J=7.0)$ & $1.48(\mathrm{~d}, J=6.5)$ & $1.01(\mathrm{~s})$ & & & & \\
\hline 18 & & & $1.33(\mathrm{~s})$ & $1.02(\mathrm{~s})$ & & & & & & \\
\hline 19 & & & $1.45(\mathrm{~s})$ & $0.84(\mathrm{~s})$ & $1.28(\mathrm{~s})$ & $1.14(\mathrm{~s})$ & & & & \\
\hline $2^{\prime}$ & & & & & & & & $7.38(\mathrm{~d}, J=8.7)$ & $7.38(\mathrm{~d}, J=8.5)$ & \\
\hline $3^{\prime}$ & $2.63(\mathrm{~s})$ & & & & & & & $6.84(\mathrm{~d}, J=8.7)$ & $6.83(\mathrm{~d}, J=8.5)$ & \\
\hline \multicolumn{11}{|c|}{$0.0 x(u, j-0.0)$} \\
\hline $5^{\prime}$ & 1.57 (s) & & & & & & & $6.84(\mathrm{~d}, J=8.7)$ & $6.83(\mathrm{~d}, J=8.7)$ & \\
\hline $6^{\prime}$ & $1.57(\mathrm{~s})$ & & & & & & & $7.38(\mathrm{~d}, J=8.7)$ & $7.38(\mathrm{~d}, J=8.5)$ & \\
\hline $1^{\prime \prime}$ & & & & & & & & $1.75(\mathrm{~m})$ & & \\
\hline $2^{\prime \prime}$ & & & & & & & & $2.09(\mathrm{~m})$ & & \\
\hline $3^{\prime \prime}$ & $2.63(\mathrm{~s})$ & & & & & & & $5.08(\mathrm{t}, J=7.1)$ & & \\
\hline \multicolumn{11}{|c|}{$0.00(1, j=-1.1)$} \\
\hline $6^{\prime \prime}$ & $1.57(\mathrm{~s})$ & & & & & & & $1.64(\mathrm{~s})$ & & \\
\hline $\mathrm{OH}-11$ & & & $4.85(\mathrm{~s})$ & & & & & & & \\
\hline $\mathrm{OH}-12$ & & & $5.81(\mathrm{~s})$ & $7.24(\mathrm{~s})$ & & & & & & \\
\hline OMe-3 & & & & & & & $3.85(\mathrm{~s})$ & & & \\
\hline OMe-5 & & & & & & & $3.85(\mathrm{~s})$ & & & \\
\hline
\end{tabular}


Table 2. ${ }^{13} \mathrm{C}$ NMR Data for Compounds 1-10 ( $\delta$ in ppm, $125 \mathrm{MHz}$ for ${ }^{13} \mathrm{C} \mathrm{NMR}$ in $\left.\mathrm{CDCl}_{3}\right)$.

\begin{tabular}{|c|c|c|c|c|c|c|c|c|c|c|}
\hline No & $1^{a}$ & 2 & 3 & 4 & 5 & 6 & 7 & 8 & 9 & 10 \\
\hline 1 & & 44.7 & 35.3 & 34.3 & 37.8 & 37.5 & 132.2 & & & 50.8 \\
\hline 2 & 160.9 & 33.7 & 33.6 & 27.6 & 18.5 & 18.1 & 104.9 & 79.8 & 75.6 & 50.2 \\
\hline 3 & 95.2 & 121.6 & 219.7 & 78.2 & 36.6 & 36.9 & 146.9 & 129.8 & 33.0 & 81.4 \\
\hline 4 & 124.0 & 133.3 & 47.7 & 39.0 & 47.3 & 47.1 & 132.9 & 122.7 & 22.2 & 35.3 \\
\hline 5 & 119.8 & 27.7 & 49.2 & 51.1 & 44.5 & 48.9 & 146.9 & 116.1 & 118.5 & 52.6 \\
\hline 6 & 121.9 & 30.5 & 74.3 & 17.2 & 21.6 & 26.1 & 104.9 & 133.6 & 133.0 & 42.6 \\
\hline 7 & 122.02 & 53.4 & 68.3 & 26.8 & 29.9 & 38.6 & 32.3 & 113.3 & 110.5 & 60.9 \\
\hline 8 & 111.2 & 26.1 & 125.3 & 145.7 & 135.1 & 154.2 & 30.4 & 144.4 & 145.3 & 74.8 \\
\hline 9 & 132.1 & 32.0 & 130.4 & 146.0 & 148.6 & 59.7 & 60.8 & 138.5 & 140.2 & 34.2 \\
\hline 10 & & 40.9 & 38.4 & 38.1 & 37.0 & 39.7 & & 121.1 & 121.1 & 32.1 \\
\hline 11 & & 74.9 & 140.0 & 183.3 & 124.4 & 20.9 & 171.1 & & & 43.1 \\
\hline 12 & & 72.1 & 142.4 & 150.6 & 122.8 & 35.4 & & & & 12.4 \\
\hline 13 & & 23.7 & 132.9 & 123.9 & 142.6 & 211.2 & & & & 30.2 \\
\hline 14 & & 18.0 & 119.7 & 187.3 & 126.0 & 125.1 & & & & 29.5 \\
\hline 15 & & 23.1 & 27.2 & 24.0 & 70.1 & 49.5 & & & & 27.3 \\
\hline 16 & & 171.2 & 22.5 & 20.0 & 24.8 & 23.8 & & & & \\
\hline 17 & & 20.9 & 22.8 & 19.8 & 184.5 & 29.1 & & & & \\
\hline 18 & & & 32.0 & 28.2 & 16.2 & 183.8 & & & & \\
\hline 19 & & & 19.0 & 15.7 & 25.0 & 16.5 & & & & \\
\hline 20 & & & 20.1 & 19.9 & & 14.6 & & & & \\
\hline $1^{\prime}$ & & & & & & & & 133.8 & 134.0 & \\
\hline $2^{\prime}$ & 86.2 & & & & & & & 127.8 & 127.9 & \\
\hline $3^{\prime}$ & 48.7 & & & & & & & 115.5 & 115.5 & \\
\hline $4^{\prime}$ & 184.0 & & & & & & & 154.7 & 154.0 & \\
\hline $5^{\prime}$ & 26.9 & & & & & & & 115.5 & 115.5 & \\
\hline $6^{\prime}$ & 26.9 & & & & & & & 127.8 & 127.9 & \\
\hline $1^{\prime \prime}$ & & & & & & & & 41.7 & & \\
\hline $2^{\prime \prime}$ & & & & & & & & 22.8 & & \\
\hline $3^{\prime \prime}$ & & & & & & & & 123.8 & & \\
\hline $4^{\prime \prime}$ & & & & & & & & 131.9 & & \\
\hline $5^{\prime \prime}$ & & & & & & & & 17.6 & & \\
\hline $6^{\prime \prime}$ & & & & & & & & 25.6 & & \\
\hline $\mathrm{Me}-2$ & & & & & & & & & $26.9(\times 2)$ & \\
\hline Me-11 & & & & & & & 20.9 & & & \\
\hline OMe-3 & & & & & & & 56.2 & & & \\
\hline OMe-5 & & & & & & & 56.2 & & & \\
\hline
\end{tabular}

${ }^{a}$ Measured in $\mathrm{CD}_{3} \mathrm{COCD}_{3}$ at $100 \mathrm{MHz}$.

The ${ }^{1} \mathrm{H}-\mathrm{NMR}$ signals of 4 at $\delta_{\mathrm{H}} 0.84(\mathrm{~s}), 1.02$ (s) and 1.22 (s); 1.19 and 1.18 (each $3 \mathrm{H}, \mathrm{d}$, $\left.J=7.0 \mathrm{~Hz}, \mathrm{CH}_{3}-16,17\right)$, and $3.12\left(\mathrm{H}-15, \mathrm{COSY}\right.$ cross-peaks with $\delta_{\mathrm{H}} 1.19$ and 1.18) suggested that $\mathbf{5}$ has an iPr group and three Me groups attached to a quatenary $\mathrm{C}$-atom. According to ${ }^{13} \mathrm{C}-\mathrm{NMR}$ and DEPT, in addition to isopropyl and three singlet methyl groups, there is a carbon at $\delta_{C} 78.24$, which is a tertiary carbon connected to oxygen, and $\delta_{C} 183.25$ and 187.31 show quinone group signals. In addition, there are four olefinic carbons, $\delta_{C} 123.85$, $150.56,145.74$ and 145.97. Since the compound is yellow and the UV absorption spectrum shows, coupled with the above-mentioned spectral data $\left({ }^{1} \mathrm{H}-\mathrm{NMR}\right.$ and ${ }^{13} \mathrm{C}-\mathrm{NMR}$ data of known compounds in Reference [10], it can be inferred that compound 4 is a derivative of hydroxybenzoquinone in the abietane skeleton. The $\mathrm{C}$ ring is a quinone ring, and $\mathrm{H}-1 \beta$ ( $\delta$ 2.79 ) is affected by the quinone group of $\mathrm{C}-11$, so the magnetic field is relatively low. From the signal of $\delta_{\mathrm{H}} 3.24(\mathrm{dd}, \mathrm{J}=10.6,5.7 \mathrm{~Hz})$, it can be seen that this $\mathrm{H}$ is in the axial position, and -OH is in the equatorial position. By heteronuclear correlation spectroscopy (HSQC, $\mathrm{HMBC}$ ) and NOESY to analyze its structural correlation and stereo orientation. According to HMBC's information as following: (1) $\delta 3.24$ is related to C-18 and C-19 respectively, so it is determined that the hydroxyl group is connected to the position of C-3; (2) H-5 is 
connected to C-3, C-7, and C-3, respectively. C-10, C-18, C-19, C-20 are connected; (3) H-15 is connected with C-12, C-13, C-14 respectively; (4) H-20 is connected with C-1. C-5, C-9, C-10 are related. According to the signal from NOESY: (1) H-5 is related to H-1 $\alpha, \mathrm{H}-3, \mathrm{H}-6 \alpha$, $\mathrm{H}-7 \alpha$, and $\mathrm{H}-18$ respectively; (2) H-3 is related to $\mathrm{H}-5$ and $\mathrm{H}-18$ Therefore, it is determined that $\mathrm{H}-3$ is in the axial direction; (3) H-20 is related to $\mathrm{H}-2 \beta$ and $\mathrm{H}-6 \beta$; (4) $\mathrm{H}-2 \beta$ is related to $\mathrm{H}-19$ and $\mathrm{H}-20$. The structure was proved to be correct, and the new compound was named amycolataiwanensin D.

Compound 5 was obtained as a colorless gum and had a molecular formula of $\mathrm{C}_{19} \mathrm{H}_{26} \mathrm{O}_{3}$ by the HR-EI-MS $\left(\mathrm{m} / z\right.$ 302.1885 $[\mathrm{M}+\mathrm{H}]^{+}$, calcd for $\mathrm{C}_{20} \mathrm{H}_{30} \mathrm{O}_{3}$ 302.1882), requiring six degrees of unsaturation. The IR spectrum of 5 displayed absorption characteristic of a hydroxy $\left(3396 \mathrm{~cm}^{-1}\right)$, carboxylic acid group $\left(2700 \sim 3400(\mathrm{OH}) \& 1697(\mathrm{C}=\mathrm{O}) \mathrm{cm}^{-1}\right)$, and benzene ring (1570 and $\left.1498 \mathrm{~cm}^{-1}\right)$. The ${ }^{13} \mathrm{C}$ NMR spectrum revealed the presence of 20 carbon signals, which were assigned with the assistance of DEPT spectrum as one $\mathrm{sp}^{2}$ quaternary carbonyl carbon $\left[\delta_{\mathrm{C}} 184.5(\mathrm{C}-18)\right]$, three $\mathrm{sp}^{3}$ methyls $\left[\delta_{\mathrm{C}} 24.8,16.2\right.$, and 25.0 $(\mathrm{C}-17,19 \& 20)]$, five $\mathrm{sp}^{3}$ methylenes $\left[\delta_{C} 37.8,18.5,36.6,21.6\right.$, and $29.9(\mathrm{C}-1,2,3,6$ \& 7)], two $\mathrm{sp}^{3}$ methines $\left[\delta_{C} 44.5\right.$, and 70.1 (C-5 and 15)], three $\mathrm{sp}^{2}$ methines $\left[\delta_{C} 124.4,122.8\right.$, and $126.0(\mathrm{C}-11,12$, and 14$)]$, two sp ${ }^{3}$ quaternary carbons $\left[\delta_{\mathrm{C}} 47.3\right.$ and $37.0(\mathrm{C}-4$ and 10$\left.)\right]$, and five $\mathrm{sp}^{2}$ quaternary carbons $\left[\delta_{C} 135.1,148.6\right.$, and $142.6(\mathrm{C}-8,9$, and 13$\left.)\right]$. The ${ }^{1} \mathrm{H}-\mathrm{NMR}$ and ${ }^{13} \mathrm{C}-\mathrm{NMR}$ spectra (Tables 1 and 2) of 5 were similar to those of 12-methoxy-13-(1-hydroxy ethyl)podocarpa-8,11,13-trien-19-oic acid [11,12], except that an aromatic proton $\left[\delta_{\mathrm{H}} 7.11\right.$ $(\mathrm{d}, J=8.2 \mathrm{~Hz}, \mathrm{H}-12)]$ of 5 replaced a methoxyl group at C-12 [ $\left.\delta_{\mathrm{H}} 3.65\left(3 \mathrm{H}, \mathrm{s}, \mathrm{OCH}_{3}\right)\right]$ of 5a. According to the DEPT-NMR spectrogram, there are three primary carbons, five secondary carbons, five tertiary carbons, and six tertiary carbons. The degree of unsaturation is estimated to be 7 , which is consistent with the predicted structure. Viewed from the HMBC spectrum, $\delta_{\mathrm{H}} 1.48(\mathrm{H}-16)$ is correlated to C-15 and C-13, and $\delta_{\mathrm{H}} 4.80(\mathrm{H}-15)$ is correlated to C-16, C-14, C-13, and C-12, could be explained the position of the doublet methyl group (Me-15) and the hydroxyl group. The stereochemistry is determined from the NOESY spectrum. H-20 and H-19 have NOESY correlation, which is sufficient to show that $-\mathrm{COOH}$ is located in the equatorial. $\mathrm{H}-1 \beta$ has NOESY association with $\mathrm{H}-11$, and $\mathrm{H}-16$ has NOESY association with $\mathrm{H}-12$ and $\mathrm{H}-14$, which are consistent with the speculated structure. Based on the above data, it can be determined that compound 5 is $\left(1 R^{*}, 4 a S^{*}\right)-7-(1-$ hydroxyethyl)-1,4a-dimethyl-1,2,3,4,4a,9,10,10a-octahydrophenanthrene-1-carboxylic acid (15-hydroxyabieta-8,11,13-trien-18-oic acid) and named as amycolataiwanensin E.

Compound 6 was isolated as oil. Its molecular formula, $\mathrm{C}_{20} \mathrm{H}_{30} \mathrm{O}_{3}$, was determined on the basis of the positive HR-EI-MS at $m / z 318.2197[\mathrm{M}]^{+}($calcd 318.2195$)$ and was supported by the ${ }^{1} \mathrm{H},{ }^{13} \mathrm{C}$, and DEPT data. The IR absorption bands of 6 revealed the presence of the $\mathrm{COOH}\left(3400 \mathrm{~cm}^{-1}\right.$ for $\mathrm{OH} ; 1699 \mathrm{~cm}^{-1}$ for CO) and a conjugated carbonyl $\left(1670 \mathrm{~cm}^{-1}\right)$ functions. According to DEPT plots, there are four primary carbons, seven secondary carbons, three tertiary carbons, and six quaternary carbons. The degree of unsaturation is estimated to be 6. In ${ }^{13} \mathrm{C}$-NMR spectrum, four signals at $\delta 29.1,23.8,16.5$, and 14.6, and ${ }^{1} \mathrm{H}-\mathrm{NMR}$ at $\delta 0.67,1.01,1.13, \& 1.14$ (each $3 \mathrm{H}, \mathrm{s}$ ), showing the presence of four Me groups. The ${ }^{13} \mathrm{C}-\mathrm{NMR}$ spectrum at $\delta 183.8$ (s) and the infrared absorption spectrum at 2700-3400, $1699 \mathrm{~cm}^{-1}$, it shows that this compound has a carboxylic acid group. In addition, $\delta 154.2$ (s), 125.1 (d) and ${ }^{1} \mathrm{H}-\mathrm{NMR}$ spectrum $\delta 5.82(1 \mathrm{H}$, br s) show that there is a group of triplesubstituted double bonds. The remaining ${ }^{13} \mathrm{C}$-NMR spectrum at $\delta 211.2$ (s) shows the existence of carbonyl group $(\mathrm{C}=\mathrm{O})$. It can be inferred that 6 contains a carboxylic acid, a set of double bonds, and a carbonyl group. The remaining unsaturation is 3 , which is inferred to be a tricyclic structure. HMBC correlations of $\delta_{\mathrm{H}} 1.01(\mathrm{H}-17) / \delta_{\mathrm{C}} 49.5(\mathrm{C}-15)$, 211.2 (C-13); $\delta 1.13$ (H-16) $\delta 49.5$ (C-15), 211.2 (C-13); $\delta 5.82$ (H-14) / $\delta 49.5$ (C-15). From the HMBC spectrum, $\delta 1.01(\mathrm{H}-17)$ is correlated to $\delta 49.5(\mathrm{C}-15), 211.2(\mathrm{C}-13) ; \delta 1.13(\mathrm{H}-$ 16) is correlated to $\delta 49.5$ (C-15), 211.2 (C-13), and the correlation between $\delta 5.82(\mathrm{H}-14)$ and $\delta 49.5$ (C-15), and the double bond signal will shift to a low magnetic field. It is speculated that the double bond is conjugated to the carbonyl group, but $\delta 211.2(\mathrm{C}-13)$ ) Unlike a conjugated carbonyl group, there may be one $\alpha$ carbon and three $\beta$ carbons, 
which makes the carbonyl shift to a lower magnetic field. From the HMBC correlations between $\delta 2.07(\mathrm{H}-9)$ and $\delta 39.7$ (C-10), 14.6 (C-20); $\delta 1.98(\mathrm{H}-5)$ and $\delta 47.1$ (C-4), $39.7(\mathrm{C}-10)$, 26.1 (C-6), 16.5 (C-19), 14.6 (C-20); $\delta 1.14$ (H-19) and $\delta 183.8$ (C-18), 47.1 (C-4), 36.9 (C -3); $\delta 5.82(\mathrm{H}-14)$ and $\delta 154.2(\mathrm{C}-8), 49.5(\mathrm{C}-15), 38.6(\mathrm{C}-7) ; \delta 1.58(\mathrm{H}-12)$ and $\delta 211.2(\mathrm{C}-13)$, 59.7 (C-9), 23.8 (C-16); $\delta 1.13(\mathrm{H}-16), 1.01$ (H-17) are related to $\delta 211.2(\mathrm{C}-13), 49.5(\mathrm{C}-15)$, $35.4(\mathrm{C}-12)$ respectively. From the above analysis of 1D and 2D spectra, compound 6 is $12(13 \rightarrow 15)$ abeoabietane diterpenes, $C-12$ is not connected to $C-13$, and $C-15$ is reversed to cause the six-ring to seven-ring, geminal dimethyl group is substituted for isopropy. As for its proposal biosynthesis and the stereochemistry, it can be explained by the NOESY spectrum. H-20 and H-19 have a NOESY correlation, which is sufficient to show that $-\mathrm{COOH}$ is located in the equatorial direction. The spectra of HMQC and COSY confirm that the compound 6 is $12(13 \rightarrow 15)$ abeo-13-oxo-8(14)-abietene-18-oic acid and designated as amycolataiwanensin $\mathrm{F}$.

Compound 7 was obtained as oil. Its molecular formula $\mathrm{C}_{13} \mathrm{H}_{18} \mathrm{O}_{5}$ was deduced from molecular ion at $\mathrm{m} / \mathrm{z} 254.1151 \mathrm{[M]}^{+}$(calcd 254.1154) in the HR-EI mass spectrum. The presence of hydroxyl $\left(3440 \mathrm{~cm}^{-1}\right)$, acetoxyl $\left(1730 \mathrm{~cm}^{-1}\right)$, and benzene $\left(1615\right.$ and $\left.1518 \mathrm{~cm}^{-1}\right)$ groups were evident from the IR spectrum. The ${ }^{1} \mathrm{H}$ (Table 1 ) and ${ }^{13} \mathrm{CNMR}$ (Table 2$)$ data of 7 were very similar to those of dihydrosyringenin [13], except that an acetoxy group $\left[\delta_{\mathrm{H}} 2.02(3 \mathrm{H}\right.$, s); $\left.\delta_{\mathrm{C}} 20.9,171.1\left(\mathrm{OCOCH}_{3}\right)\right]$ at $\mathrm{C}-9$ in 7 replaced the hydroxy group of dihydrosyringenin. This was supported by $\mathrm{HMBC}$ correlation between $\mathrm{OCH}_{2}-9\left(\delta_{\mathrm{H}} 3.76\right)$ and $\mathrm{C}-11\left(\delta_{\mathrm{C}} 171.1\right)$ (Figure 2). The full assignment of ${ }^{1} \mathrm{H}$ and ${ }^{13} \mathrm{C}$ NMR resonances was supported by ${ }^{1} \mathrm{H}-{ }^{1} \mathrm{H}$ COSY, DEPT, HSQC, NOESY, and HMBC (Figure 2) spectral analyses. Thus, the structure of 7 was established as shown in Figure 1, and named amycolataiwanensin G.

Compound 8 was isolated as oil. Its molecular formula, $\mathrm{C}_{17} \mathrm{H}_{18} \mathrm{O}_{3}$, was determined on the basis of the HR-EI-MS at $m / z 270.1252[\mathrm{M}]^{+}$(calcd 270.1256) and was supported by the ${ }^{1} \mathrm{H},{ }^{13} \mathrm{C}$, and DEPT. The IR absorption bands of 8 revealed the presence of hydroxyl $\left(3400 \mathrm{~cm}^{-1}\right)$ and benzene (1614 and $\left.1520 \mathrm{~cm}^{-1}\right)$ functions. The ${ }^{1} \mathrm{H}$ (Table 1$)$ and ${ }^{13} \mathrm{C}$ NMR (Table 2) data of 8 were similar to those of oblongifoliagarcinine $\mathrm{A}$, [14] except that a 4-methylpent-3-en-1-yl group [ $\delta_{\mathrm{H}} 5.08\left(1 \mathrm{H}, \mathrm{t}, J=7.1 \mathrm{~Hz}, \mathrm{H}-3^{\prime \prime}\right), 1.59\left(3 \mathrm{H}, \mathrm{s}, \mathrm{CH}_{3}-6^{\prime \prime}\right) 1.64$ (3H, s, $\left.\mathrm{CH}_{3}-5^{\prime \prime}\right), 2.09$ (2H, m, H-2") 1.75 (2H, m, H-1"); $\delta_{\mathrm{C}} 22.8$ (C-2"), 123.8 (C-3"), 131.9 $\left.\left(\mathrm{C}-4^{\prime \prime}\right), 25.6\left(\mathrm{C}-6^{\prime \prime}\right), 17.6\left(\mathrm{C}-5^{\prime \prime}\right), 41.7\left(\mathrm{C}-1^{\prime \prime}\right)\right]$ at $\mathrm{C}-2$ in 8 replaced the Me group at $\mathrm{C}-2$ of oblongifoliagarcinines A [14]. This was supported by NOESY correlations between Me-2 $\left(\delta_{\mathrm{H}} 1.42\right)$ and $\mathrm{H}-2^{\prime \prime}\left(\delta_{\mathrm{H}} 2.09\right)$, and between $\mathrm{H}-3^{\prime \prime}\left(\delta_{\mathrm{H}} 5.08\right)$ and both of $\mathrm{CH}_{3}-6^{\prime \prime}\left(\delta_{\mathrm{H}} 1.64\right)$ and $H-1^{\prime \prime}\left(\delta_{\mathrm{H}} 1.75\right)$ and by HMBC correlation between $\mathrm{H}-1^{\prime \prime}\left(\delta_{\mathrm{H}} 1.75\right)$ and $\mathrm{C}-3$ \& $9\left(\delta_{\mathrm{C}} 129.8\right.$ \& 138.5) (Figure 2). The full assignment of ${ }^{1} \mathrm{H}$ and ${ }^{13} \mathrm{C}$ NMR resonances was further confirmed by DEPT, ${ }^{1} \mathrm{H}-{ }^{1} \mathrm{H}$ COSY, NOESY, HSQC, and HMBC data (Figure 2). Consequently, the structure of compound $\mathbf{8}$ was established as amycolataiwanensin $\mathrm{H}$.

Compound 9 was obtained as oil and had the molecular formula $\mathrm{C}_{22} \mathrm{H}_{24} \mathrm{O}_{3}$, as inferred from the HR-EI-MS showing the molecular-ion peak at $m / z 336.1728[\mathrm{M}]^{+}$, indicating nine degrees of unsaturation. The IR spectrum of 9 showed absorption bands at $3395 \mathrm{~cm}^{-1}$ for free $\mathrm{OH}$ groups, 1613, 1596, 1520, $1486 \mathrm{~cm}^{-1}$ for aromatic moieties. The ${ }^{1} \mathrm{H}-\mathrm{NMR}$ and ${ }^{13} \mathrm{C}$-NMR spectra (Tables 1 and 2) of 9 were similar to those of oblongifoliagarcinines A [14], except that the single bond at C3-C4 [ $\delta_{\mathrm{H}} 2.78(2 \mathrm{H}, \mathrm{t}, J=6.7 \mathrm{~Hz}, \mathrm{H}-4), 1.83(2 \mathrm{H}, \mathrm{t}$, $J=6.7 \mathrm{~Hz}, \mathrm{H}-3)]$ of 9 replaced a pair of double bond $\left[\delta_{\mathrm{H}} 5.65(2 \mathrm{H}, \mathrm{d}, J=9.8 \mathrm{~Hz}, \mathrm{H}-4)\right.$, $6.37(2 \mathrm{H}, \mathrm{d}, J=9.8 \mathrm{~Hz}, \mathrm{H}-3)]$ of oblongifoliagarcinines A [14]. The ${ }^{1} \mathrm{H}$-and ${ }^{13} \mathrm{C}-\mathrm{NMR}$ (Tables 1 and 2) and HMBC data (Figure 2) established the structure of amycolataiwanensin I (9) as 6-(4-hydroxyphenyl)-2,2-dimethylchroman-8-ol.

Fifteen ${ }^{13} \mathrm{C}$-NMR signals and the HR-EI-MS confirmed the molecular formula $\mathrm{C}_{15} \mathrm{H}_{26} \mathrm{O}_{2}$ of 10. Analysis of its IR spectrum suggested that $\mathbf{1 0}$ contained $\mathrm{OH}\left(3299 \mathrm{~cm}^{-1}\right)$ moiety. The three IHD (from the DEPT experiment), the ${ }^{13} \mathrm{C}-\mathrm{NMR}$ data, and the molecular formula indicated that $\mathbf{1 0}$ is a sesquiterpene. Further spectral data established the structure of 10 as $\left(2 S^{*}, 3 S^{*}, 6 R^{*}\right)$-3,6,8,8-tetramethyloctahydro- $1 H$-3a,7-methanoazulene-2,6-diol ( $3 \alpha$ hydroxycedrol). The ${ }^{1} \mathrm{H}-\mathrm{NMR}$ shows that $\delta_{\mathrm{H}} 0.94(\mathrm{~d})$ is a doublet methyl group attached to a tertiary carbon. At $\delta_{\mathrm{H}} 1.00$ (s), 1.23 (s), and 1.32 (s), there are three singlet methyl groups 
on the quaternary carbon. Among them, $\delta_{\mathrm{H}} 1.23(\mathrm{~s})$ and $1.32(\mathrm{~s})$ are located in the lower magnetic field because they are connected to the hydroxyl group. From ${ }^{13} \mathrm{C}-\mathrm{NMR}, \mathrm{DEPT}$, and HSQC plots, there are two carbons attached to oxygen at $\delta_{C} 72.84$ and $81.43,72.84$ belongs to the quaternary carbon, and $\delta_{C} 81.43$ belongs to the tertiary carbon. Calculating the degree of unsaturation, because there is no double bond or carbonyl carbon, it can be proposed this compound is a tricyclic ring. Based on the above spectral data, it is speculated that the compound should be a cedrane skeleton. After comparing with the reference data, and comparing with the ${ }^{1} \mathrm{H}-\mathrm{NMR}$ and ${ }^{13} \mathrm{C}-\mathrm{NMR}$ of the known compound cedrol [15], there is only one more oxygen-containing tertiary carbon. It can be confirmed by the signal $\left(\delta_{\mathrm{H}} 3.58(1 \mathrm{H}, \mathrm{ddd}, J=15.5,10.5,5.5 \mathrm{~Hz}, \mathrm{H}-3) ; \delta_{\mathrm{C}} 81.4\right)$ appeared on the ${ }^{1} \mathrm{H}-\mathrm{NMR} \&{ }^{13} \mathrm{C}-\mathrm{NMR}$. Continue to perform two-dimensional heteronuclear correlation spectroscopy (HSQC, HMBC) and NOESY to further determine the structural relevance and stereo orientation of 10. The ${ }^{1} \mathrm{H}$ signal at $\delta_{\mathrm{H}} 1.45(\mathrm{H}-2) / \delta_{\mathrm{H}} 1.36\left(\mathrm{CH}_{2}-4\right)$ and $\delta_{\mathrm{H}} 0.94$ $\left(\mathrm{CH}_{3}-12\right)$ showed a two and three-bond connectivities with $\mathrm{C}-3\left(\delta_{\mathrm{C}} 81.4\right)$ in the HMBC plot (Figure 2), which suggested that the second $\mathrm{OH}$ group at $\mathrm{C}-3$. According to the signals from NOESY, determine the relative configuration of the C-3 and C-8 hydroxyl groups: (1) Compound 3 exhibited the HMBC correlation: H-3/12-Me, and judging from the split pattern (ddd), $\mathrm{H}-3$ is located in the $\beta$-axial position; (2) $15-\mathrm{CH}_{3}$ is correlated to $\mathrm{H}-9 \alpha$ and $\mathrm{H}-9 \beta$, so it is judged that $15-\mathrm{CH}_{3}$ is equatorial. The structure was proved to be correct, and compared with the literature, it was confirmed that this was a compound discovered for the first time in nature, named amycolataiwanensin J.

$\mathrm{NO}$ is a mediator in the inflammatory response involved in host defense. In the course of our search for potential diverse secondary metabolites from natural fungal sources, and to further understanding of the bioactive metabolites of the genus Amycolatopsis, we examined the EtOAc extract of A. taiwanensis, which showed inhibitory activity on LPSinduced NO release production in RAW 264.7 murine macrophages, as determined by our primary screening (approximately 95\% inhibition at a concentration of $10 \mu \mathrm{g} / \mathrm{mL}$ ). Investigation of the bioactive metabolites of the active EtOAc extract from the titled material A. taiwanensis, led to the isolation of ten new compounds. Due to the small quantity of isolated compound (1), we evaluated the inhibitory effects of amycolataiwanensins B-J (2-10, resp.) on the production of NO induced by LPS. The inhibitory activity data of the 10 isolated compounds on NO generation by macrophages are shown in Table 3. From the results of our anti-inflammatory tests, the following conclusions can be drawn: $(a)$ They showed potent inhibition with $\mathrm{IC}_{50}$ values between 12.8 to $34.2 \mu \mathrm{M}$, against lipopolysaccharide (LPS)-induced nitric oxide (NO) generation. (b)The high cell viability $(>80 \%)$ indicated that the inhibitory activity of LPS-induced nitrite production by compounds 3, 5, 8, and 9 ( $\mathrm{IC}_{50}$ value: 17.52, 12.31, 17.81 and $\left.13.32 \mu \mathrm{M}\right)$ did not result from its cytotoxicity. (c) Compounds 6 \& 7 ( $\mathrm{IC}_{50}$ value: 24.83 and $12.78 \mu \mathrm{M}$ ) also showed inhibition of NO production of macrophages, but the low cell viability $(<80 \%)$ suggested the possibility of cytotoxicity. $(d)$ The sesquiterpene derivative, compound 2 exhibited less effective NO inhibition. (e) Among the abietane diterpene analogues, compound 3 (with (abietane with 3-isopropylbenzene-1,2-diol unit in $C$ ring) exhibited more effective inhibition than its analogue, compound 4 (abietane with hydroxybenzoquinone unit in $C$ ring), compound 5 (with 1-phenylethan-1-ol moiety in C ring) and compound 6 (with 7,7-dimethylcyclohept2-en-1-one moiety in $C$ ring. $(f)$ Among the aromatics analogues, compound 7 (simple aromatic with 9-acetoxydihydrosyringenin) displayed better inhibition than its analogue, compound 8 (abietane with hydroxybenzoquinone unit in $\mathrm{C}$ ring), compound 5 (with 1-phenylethan-1-ol moiety in C ring) and compound 9 (with 7,7-dimethylcyclohept-2-en-1one moiety in C ring. $(g)$ Furthermore, the RT-PCR analysis in the present study indicated that LPS treatment increased the level of iNOS mRNA expression, and that compounds 3, 5, 8 and 9 inhibited this increase in a concentration-dependent manner. At the highest concentration, none of the compounds tested showed any obvious cytotoxicity toward RAW 264.7 cells. (h) Cytotoxic effects were measured using MTT assay. The high cell 
viability ( $>95 \%$ ) indicated that the inhibitory activities of LPS-induced NO production by active compounds $3,5,8$, and 9 were not resulted from its cytotoxicity.

Table 3. Inhibitory Effects of the 9 isolates (2-10) from Amycolatopsis taiwanensis on LPS-activated NO productions in RAW 264.7 macrophages.

\begin{tabular}{ccc}
\hline \multirow{2}{*}{ Compounds } & \multicolumn{2}{c}{$\left.\mathrm{IC}_{\mathbf{5 0}}(\boldsymbol{\mu \mathbf { M }})^{\mathbf{a}}\right)$} \\
\cline { 2 - 3 } & NO & Cell Viability (\% Control) \\
\hline Amycolataiwanensin B (2) & $34.23 \pm 1.97^{*}$ & $99.62 \pm 5.53$ \\
Amycolataiwanensin C (3) & $17.52 \pm 1.85^{*}$ & $95.53 \pm 3.39$ \\
Amycolataiwanensin D (4) & $24.75 \pm 1.63^{*}$ & $91.12 \pm 4.22$ \\
Amycolataiwanensin E (5) & $12.31 \pm 4.97^{* *}$ & $82.22 \pm 3.21$ \\
Amycolataiwanensin F (6) & $24.83 \pm 12.91^{* *}$ & $56.35 \pm 5.48$ \\
Amycolataiwanensin G (7) & $12.78 \pm 4.82^{*}$ & $95.91 \pm 3.91$ \\
Amycolataiwanensin H (8) & $17.81 \pm 1.132^{* *}$ & $98.03 \pm 1.53$ \\
Amycolataiwanensin I (9) & $13.32 \pm 0.51^{*}$ & $89.50 \pm 2.15$ \\
Amycolataiwanensin J (10) & $>100$ & $94.11 \pm 1.32$ \\
Quercetin b & $35.94 \pm 2.34^{*}$ & \\
\hline
\end{tabular}

${ }^{\mathrm{a}}$ The $\mathrm{IC}_{50}$ values were calculated from the slope of the dose-response curves (SigmaPlot). Values are expressed as mean $\pm \operatorname{SEM}(n=4)$ of 3 independent experiments. ${ }^{*} p<0.05,{ }^{* *} p<0.01$ compared with the control. ${ }^{\mathrm{b}}$ Quercetin was used as a positive control.

\section{Materials and Methods}

\subsection{General Experimental Procedures}

The following instruments were used for obtaining physical and spectroscopic data: optical rotations Jasco DIP-370 polarimeter; in $\mathrm{CHCl}_{3}$ (JASCO, Kyoto, Japan); FTIR spectra were obtained by using a FTIR spectrometer (Perkin-Elmer-2000 FT-IR spectrophotometer; $v$ in $\mathrm{cm}^{-1}$, Norwalk, CT, USA); Absorption spectra were recorded by an ultraviolet visible (UV-vis) light spectrophotometer (Jasco UV-240 spectrophotometer; $\lambda_{\max }(\log \varepsilon$ ) in $\mathrm{nm}$, Hitachi, Ltd., Tokyo, Japan), EI and HREIMS: Jeol JMS-HX-300 mass spectrometer; in $\mathrm{m} / \mathrm{z}$ (rel. \%) and JEOL SX-102A Mass Spectrometer; melting point, MP-J3 (Yanaco, Kyoto, Japan); NMR spectra were taken on a Varian-Mercury-500 and Varian-Unity-Plus-400 spectrometers with TMS as an internal standard (Lake Forest, California USA). Silica gel column chromatography was performed on silica gel (70-230 mesh, Merck, Darmstadt, Germany). HPLC was performed on a Shimadzu LDC-Analytical-III apparatus equipped with an UV-VIS detector (SPD-10A). A Spherical C18 column $(250 \times 10 \mathrm{~mm}, 5 \mu \mathrm{m})$ was used for preparative purposes (flow rate: $2.00 \mathrm{~mL} / \mathrm{min}$ ). Aluminum pre-coated silica gel (Merck, Kieselgel 60 F254) were used for TLC monitoring with visualization by spraying with a $10 \%$ solution of $\mathrm{Ce}_{2} \mathrm{SO} 4$ in ethanol and heating to approximately $100{ }^{\circ} \mathrm{C}$ on a hotplate.

\subsection{Microorganism}

Amycolatopsis taiwanensis $\left(0345 \mathrm{M}-7^{\mathrm{T}}\right)$ was used throughout this study, and deposited at Bioresource Collection and Research Center (BCRC), Food Industry Research and Development Institute (FIRDI). This actinobacteria was identified by Min Tseng., and specimens $\left(0345 \mathrm{M}-7^{\mathrm{T}}\right)$ deposited at the Bioresource Collection and Research Center (BCRC) of the Food Industry Research and Development Institute (FIRDI).

\subsection{Cultivation and Preparation of the Fungal Strain}

The actinobacteria, Amycolatopsis taiwanensis $\left(0345 \mathrm{M}-7^{\mathrm{T}}\right)$, was isolated from a sediment collected from the northern area of Taiwan, by using HVY agar, and was then incubated at $45^{\circ} \mathrm{C}$ for 7 days. This actinobacteria was identified by one of the authors (Mrs. Min Tseng), and specimens $\left(0345 \mathrm{M}-7^{\mathrm{T}}\right)$ deposited at the Bioresource Collection and Research Center (BCRC) of the Food Industry Research and Development Institute (FIRDI). The strain was maintained on oatmeal agar and the spores or mycelia suspension were harvest with $20 \%(v / v)$ glycerol and stored at $-20^{\circ} \mathrm{C}$. A mature slant culture of strain $0345 \mathrm{M}-7^{\mathrm{T}}$ was inoculated into a $500 \mathrm{~mL}$ flask containing $100 \mathrm{~mL}$ of the seed medium consisting of 
$0.4 \%$ glucose, $0.4 \%$ yeast extract, and $1 \%$ malt extract ( $\mathrm{pH} 7.3$ ). After growing at $30{ }^{\circ} \mathrm{C}$ for $4 \mathrm{~d}$ on a rotary shaker $(200 \mathrm{rpm})$, the aliquots $(2 \mathrm{~mL})$ of seed culture were transferred into a $500 \mathrm{~mL}$ flask containing $200 \mathrm{~mL}$ of production medium (Humic acid $1.0 \mathrm{~g}, \mathrm{Na}_{2} \mathrm{HPO}_{4} 0.5 \mathrm{~g}$, $\mathrm{KCl} 1.7 \mathrm{~g}, \mathrm{MgSO}_{4} 7 \mathrm{H}_{2} \mathrm{O} 0.05 \mathrm{~g}, \mathrm{FeSO}_{4} \cdot 7 \mathrm{H}_{2} \mathrm{O} 0.01 \mathrm{~g}, \mathrm{CaCO}_{3} 0.02 \mathrm{~g}$, Yeast extract $1.0 \mathrm{~g}$, Agar $20.0 \mathrm{~g}$, Dist. Water $1.0 \mathrm{~L}, \mathrm{pH} 7.4)$. After 21 days cultivation at $30{ }^{\circ} \mathrm{C}$ temperature on a rotary shaker $(500 \mathrm{rpm})$, the culture filtrates $(10 \mathrm{~L})$ were obtained by filtering through filter paper.

\subsection{Isolation and Characterization of Secondary Metabolites}

The liquid fermentation $\left(\mathrm{H}_{2} \mathrm{O}\right)$ of $A$. taiwanensis $(10 \mathrm{~L})$ was extracted with EtOAc, and the EtOAc-layer $(16.0 \mathrm{~g})$ was subjected to $\mathrm{CC}\left(\mathrm{SiO}_{2}\right.$; hexane/acetone gradient) to get six fractions (Frs. 1-6). Fr. 1 was subjected to MPLC (RP-18; $\mathrm{MeOH} / \mathrm{H}_{2} \mathrm{O} 2: 1$ ) to produce 11 fractions, Frs. 1.1-1.11. Fr. 1.2 yielded 4 (3.6 mg). Fr. 1.11 was further purified with prep. TLC (hexane $\left./ \mathrm{CH}_{2} \mathrm{Cl}_{2} 6: 1\right)$ to obtain $1(0.8 \mathrm{mg})$. Fr. 2 was subjected to $\mathrm{MPLC}\left(\mathrm{SiO}_{2}\right.$; hexane/acetone 6:1) to produce 14 fractions, Fr. 2.1-2.14. Fr. 2.4 was subjected to MPLC $\left(\mathrm{SiO}_{2}\right.$; hexane/acetone $\left.4: 1\right)$ to produce four fractions, Fr. 2.4.1-2.4.4. Fr. 2.4.4 was further purified with prep. TLC $\left(\mathrm{CH}_{2} \mathrm{Cl}_{2} / \mathrm{AcOEt} 10: 1\right)$ to obtain $5(4.6 \mathrm{mg}), 2(3.1 \mathrm{mg}), 3\left(R_{\mathrm{f}} 0.51\right.$; $0.4 \mathrm{mg})$, and $10(2.7 \mathrm{mg})$. Fr. 3 was subjected to MPLC (RP-18; acetone $\left./ \mathrm{H}_{2} \mathrm{O} 1: 2\right)$ to produce seven fractions, Frs. 3.1-3.7. Fr. 3.1 was subjected to $\mathrm{MPLC}\left(\mathrm{SiO}_{2} ; \mathrm{CH}_{2} \mathrm{Cl}_{2}\right.$ /acetone, 10/1) to obtain 8 (6.3 mg). Fr. 3.6 was subjected to MPLC (RP-18; $\left.\mathrm{MeOH} / \mathrm{H}_{2} \mathrm{O} 1: 2\right)$ to produce 9 (4.1 mg), 6 (3.1 mg). Fr. 3.7 was further purified with prep. TLC (hexane/EtOAc 1:1) to obtain 7 (1.7 mg). Frs.4 and 5 are combined together after TLC analysis and were subjected to MPLC (RP-18; $\mathrm{MeOH} / \mathrm{H}_{2} \mathrm{O} 2.5: 1$ ) to produce five fractions, Frs. 4.1-4.5. Fr. 4.2 was subjected to MPLC $\left(\mathrm{SiO}_{2} ; \mathrm{CH}_{2} \mathrm{Cl}_{2} / \mathrm{MeOH} 5: 1\right)$ to produce 5 fractions, Fr. 4.2.1-4.2.5. Fr. 4.2.4 was further purified with HPLC (RP-18; $\left.\mathrm{MeOH} / \mathrm{H}_{2} \mathrm{O} 1: 2\right)$ to obtain 5 ( $t_{\mathrm{R}} 12 \mathrm{~min}$; $2 \mathrm{~mL} / \mathrm{min} ; 4.7 \mathrm{mg})$.

Amycolataiwanensin A (1): oil; UV (MeOH): 241 (4.20), 264 (3.68), 310 (3.88) nm; IR (Neat): $3194(\mathrm{NH}), 1738(\mathrm{C}=\mathrm{O}), 1633,1614,1590$ (aromatic $\mathrm{C}=\mathrm{C}) \mathrm{cm}^{-1} ;{ }^{1} \mathrm{H}$ NMR $(400$ $\left.\mathrm{MHz}, \mathrm{CD}_{3} \mathrm{COCD}_{3}\right)$ : see Table $1 ;{ }^{13} \mathrm{C} \mathrm{NMR}\left(100 \mathrm{MHz}, \mathrm{CD}_{3} \mathrm{COCD}_{3}\right)$ : see Table 2); HREIMS $m / z 215.0948[\mathrm{M}]^{+}$(calcd for $\mathrm{C}_{13} \mathrm{H}_{13} \mathrm{NO}_{2}, 215.0946$ ).

Amycolataiwanensin B (2): oil; $[\alpha]_{\mathrm{D}}^{25}=+17.0$ (c 0.48, $\left.\mathrm{CHCl}_{3}\right)$; IR (Neat): $3500(\mathrm{OH})$, 1740 (ester $\mathrm{C}=\mathrm{O}) \mathrm{cm}^{-1} ;{ }^{1} \mathrm{H}$ NMR $\left(500 \mathrm{MHz}, \mathrm{CDCl}_{3}\right)$ : see Table $1 ;{ }^{13} \mathrm{C} \mathrm{NMR}(125 \mathrm{MHz}$, $\mathrm{CDCl}_{3}$ ): see Table 2); EIMS (70 eV) m/z (\%): $262\left[\mathrm{M}-\mathrm{H}_{2} \mathrm{O}\right]^{+}(10), 202$ (14), 132 (100), 119 (91), 57 (98); HREIMS m/z 262.1933 [M- $\left.\mathrm{H}_{2} \mathrm{O}\right]^{+}$(calcd for $\mathrm{C}_{17} \mathrm{H}_{26} \mathrm{O}_{2}, 262.1930$ ).

Amycolataiwanensin C (3): oil; $[\alpha]_{\mathrm{D}}^{25}=-56.2$ (c $\left.0.075, \mathrm{CHCl}_{3}\right) ; \mathrm{UV}(\mathrm{MeOH}): 265$ (3.86) nm; IR (Neat): $3399(\mathrm{OH}), 1694(\mathrm{C}=\mathrm{O}), 1609,1450$ (aromatic C = C) cm ${ }^{-1}$; ${ }^{1} \mathrm{H}$ NMR (500 $\left.\mathrm{MHz}, \mathrm{CDCl}_{3}\right)$ : see Table $1 ;{ }^{13} \mathrm{C} \mathrm{NMR}\left(125 \mathrm{MHz}, \mathrm{CDCl}_{3}\right)$ : see Table 2); EIMS $(70 \mathrm{eV}) \mathrm{m} / \mathrm{z}$ (\%): $330\left[\mathrm{M}-\mathrm{H}_{2} \mathrm{O}\right]^{+}(100), 229$ (86), 83 (75), 55 (64); HREIMS m/z $330.1822\left[\mathrm{M}-\mathrm{H}_{2} \mathrm{O}\right]^{+}$(calcd $^{\circ}$ for $\left.\mathrm{C}_{16} \mathrm{H}_{16} \mathrm{O}_{4}, 330.1826\right)$.

Amycolataiwanensin D (4): oil; $]_{\mathrm{D}}^{25}=-85.2$ (c 0.17, $\left.\mathrm{CHCl}_{3}\right)$; UV (MeOH): 272 (4.26), 352 (3.64) nm; IR (Neat): $3516(\mathrm{OH}), 1637$ (conjugated $\mathrm{C}=\mathrm{O}) \mathrm{cm}^{-1}$; ${ }^{1} \mathrm{H}$ NMR $(500 \mathrm{MHz}$, $\left.\mathrm{CDCl}_{3}\right)$ : see Table $\left.1 ;{ }^{13} \mathrm{C} \mathrm{NMR} \mathrm{(125} \mathrm{MHz}, \mathrm{CDCl}_{3}\right)$ : see Table 2); EIMS (70 eV) m/z (\%): $332\left([\mathrm{M}]^{+}, 100\right), 299$ (31), 231 (15), 69 (26), 59 (22); HREIMS m/z 332.1980 [M] $^{+}$(calcd for $^{2}$ $\left.\mathrm{C}_{20} \mathrm{H}_{28} \mathrm{O}_{4}, 332.1982\right)$.

Amycolataiwanensin E (5): oil; $]_{\mathrm{D}}^{25}=+31.0$ ( c 0.11, $\left.\mathrm{CHCl}_{3}\right)$; UV (MeOH): 218 (3.60), 256 (2.90) nm; IR (Neat): $3396(\mathrm{OH}), 2700 \sim 3400(\mathrm{COOH}), 1697$ ( $\underline{\mathrm{COOH}}), 1570,1498$ (aromatic $\mathrm{C}=\mathrm{C}) \mathrm{cm}^{-1} ;{ }^{1} \mathrm{H}$ NMR $\left(500 \mathrm{MHz}, \mathrm{CDCl}_{3}\right)$ : see Table $1 ;{ }^{13} \mathrm{C} \mathrm{NMR}\left(125 \mathrm{MHz}, \mathrm{CDCl}_{3}\right)$ : see Table 2); EIMS (70 eV) m/z (\%): 302 ([M] $\left.]^{+}, 30\right), 287$ (100), 269 (39), 241 (40), 197 (70); HREIMS $m / z 302.1882[\mathrm{M}]^{+}$(calcd for $\mathrm{C}_{20} \mathrm{H}_{30} \mathrm{O}_{3}, 302.1883$ ).

Amycolataiwanensin F (6): oil; ] $]_{\mathrm{D}}^{25}=+9.2$ ( $\left.c 0.56 \mathrm{CHCl}_{3}\right)$; UV (MeOH): 241 (3.70) nm; IR (Neat): $3400(\mathrm{COOH}), 1691(\underline{\mathrm{COOH}}), 1670$ (conjugated $\mathrm{C}=\mathrm{O}) \mathrm{cm}^{-1},{ }^{1} \mathrm{H} \mathrm{NMR}(500 \mathrm{MHz}$, $\left.\mathrm{CDCl}_{3}\right)$ : see Table $1 ;{ }^{13} \mathrm{C}$ NMR $\left(125 \mathrm{MHz}, \mathrm{CDCl}_{3}\right)$ : see Table 2$)$; EIMS $(70 \mathrm{eV}) \mathrm{m} / \mathrm{z}(\%): 318$ $\left([\mathrm{M}]^{+}, 18\right), 152$ (100), 137 (18), 121 (22), 109 (25); HREIMS m/z $318.2193[\mathrm{M}]^{+}$(calcd for $^{2}$ $\left.\mathrm{C}_{20} \mathrm{H}_{30} \mathrm{O}_{3}, 318.2195\right)$. 
Amycolataiwanensin G (7): oil; UV (MeOH): 233 (3.80) nm; IR (Neat): 3440 (OH), 1730 $(\mathrm{C}=\mathrm{O}), 1611,1518($ aromatic $\mathrm{C}=\mathrm{C}) \mathrm{cm}^{-1} ;{ }^{1} \mathrm{H}$ NMR $\left(500 \mathrm{MHz}, \mathrm{CDCl}_{3}\right)$ : see Table $1 ;{ }^{13} \mathrm{C}$ $\operatorname{NMR}\left(125 \mathrm{MHz}, \mathrm{CDCl}_{3}\right)$ : see Table 2); EIMS (70 eV) m/z (\%): $254\left([\mathrm{M}]^{+}, 53\right), 194$ (29), 167 (100), 151 (14); HREIMS m/z 254.1151 [M] ${ }^{+}$(calcd for $\mathrm{C}_{13} \mathrm{H}_{18} \mathrm{O}_{5}, 254.1154$ ).

Amycolataiwanensin $\mathrm{H}(8)$ : oil; $]_{\mathrm{D}}^{25}=+13.5$ (c 0.36, $\left.\mathrm{CHCl}_{3}\right)$; UV (MeOH): 258 (4.20) nm; IR (Neat): $3400(\mathrm{OH}), 1614,1520$ (aromatic $\mathrm{C}=\mathrm{C}$ ) $\mathrm{cm}^{-1} ;{ }^{1} \mathrm{H}$ NMR $\left(500 \mathrm{MHz}, \mathrm{CDCl}_{3}\right)$ : see Table 1; ${ }^{13} \mathrm{C}$ NMR (125 MHz, $\mathrm{CDCl}_{3}$ ): see Table 2); EIMS (70 eV) m/z (\%): $270\left([\mathrm{M}]^{+}, 53\right), 248$ (12), 214 (100), 188 (18). HREIMS m/z $270.1252[\mathrm{M}]^{+}$(calcd for $\mathrm{C}_{17} \mathrm{H}_{18} \mathrm{O}_{3}, 270.1256$ ).

Amycolataiwanensin I (9): oil; UV (MeOH): 224 (4.20), 268 (3.69) nm; IR (Neat): 3391 $(\mathrm{OH}), 1613,1520$ (aromatic $\mathrm{C}=\mathrm{C}) \mathrm{cm}^{-1} ;{ }^{1} \mathrm{H} \mathrm{NMR}\left(500 \mathrm{MHz}, \mathrm{CDCl}_{3}\right)$ : see Table $1 ;{ }^{13} \mathrm{C}$ NMR (125 $\left.\mathrm{MHz}, \mathrm{CDCl}_{3}\right)$ : see Table 2); EIMS (70 eV) m/z (\%): 336 ([M] $\left.]^{+}, 22\right), 253$ (100), 69 (5); HREIMS $m / z 336.1728[\mathrm{M}]^{+}$(calcd for $\mathrm{C}_{22} \mathrm{H}_{24} \mathrm{O}_{3}, 336.1725$ ).

Amycolataiwanensin J (10): oil; $]_{\mathrm{D}}^{25}=+34.8$ (c 0.01, $\left.\mathrm{CHCl}_{3}\right)$; IR (Neat): $3299(\mathrm{OH}) ;{ }^{1} \mathrm{H}$ NMR (500 MHz, $\left.\mathrm{CDCl}_{3}\right)$ : see Table $1 ;{ }^{13} \mathrm{C} \mathrm{NMR} \mathrm{(125} \mathrm{MHz}_{\mathrm{CDCl}}$ ): see Table 2); EIMS (70 eV) m/z (\%): 238 ([M] $\left.{ }^{+}, 10\right), 220(10), 167$ (100),149 (31), 107 (34); HREIMS m/z 238.1930 $[\mathrm{M}]^{+}$(calcd for $\mathrm{C}_{15} \mathrm{H}_{26} \mathrm{O}_{2}, 238.1932$ ).

\subsection{Determination of NO Production and Cell Viability Assay}

Mouse macrophage cell line (RAW 264.7) was obtained from Bioresource Collection and Research Center (BCRC 60001) and cultured at $37^{\circ} \mathrm{C}$ in Dulbecco's Modified Eagle's Medium (DMEM) supplemented with 10\% fetal bovine serum (Gibco), $4.5 \mathrm{~g} / \mathrm{L}$ glucose, $4 \mathrm{mM}$ glutamine, penicillin (100 units $/ \mathrm{mL})$, and streptomycin $(100 \mu \mathrm{g} / \mathrm{mL})$ in a humidified atmosphere in a $5 \% \mathrm{CO}_{2}$ incubator. The cells were treated with $10,25,50 \mu \mathrm{M}$ natural products in the presence of $1 \mu \mathrm{g} / \mathrm{mL}$ LPS (lipopolysaccharide, Sigma-Aldrich, St. Louis, $\mathrm{MO}, \mathrm{USA}$ ) for $20 \mathrm{~h}$. The concentration of $\mathrm{NO}$ in culture supernatants was determined as nitrite, a major stable product of NO, by Griess reagent assay [16], and cell viabilities were determined using the MTT assay as described previously [17].

\section{Conclusions}

Actinobacteria have the ability to produce a variety of physiologically active products, so they play a very important role in the food and pharmaceutical industries. Over the years, our team has also separated and collected actinomycetes resources from all over Taiwan and various environments. In addition to common Streptomyces, there are also many rare species of actinobacteria, and there are many new species. Based on the concept of "new species and new compounds", it is expected that special compounds can be found from these new strains. In recent years, studies have also found that these new species of actinobacteria can produce many active secondary metabolites. In order to further explore the efficacy of different strains of actinobacteria and expand the application range of actinomycetes, therefore, this project uses one new species of actinobacteria that have not been studied in the past, and they are cultured, extracted, purified and identified with high-level and highly active anti-inflammatory compounds with solid rice, in order to improve the research of actinobacteria in my country level, and develop health products related to actinobacteria. Under the support of the Ministry of Economic Affairs, the Bioresource Collection and Research Center at Food Industry Research and Development Institute, has been dedicated to the research work on the collection, separation and preservation of bio-resource research in the past few years, and has constructed a complete indigenous strains resource bank in Taiwan. The applicant analyzed the active constituents from it, and obtained more than sixty active new compounds isolated from red yeast rice, endophytes, actinobacteria, and mushrooms, among which many new compounds have anti-cancer and anti-inflammatory effects. Most of them have been published [18-23]. According to those findings, we have proved that the exploration of bioactive compounds on indigenous strains in Taiwan is a research-worthy topic. Actinobacteria are well known as an outstanding source of commercially valuable bioactive compounds, particularly antibiotics. Many microbial bioactive metabolites are derived from actinomycetes (Streptomyces sp.). 
However, the metabolites of many new Taiwanese actinobacteria and their mechanisms of actions are still unknown. It is necessary to study on the bioactive by scientific methods from these rare actinobacteria. In summary, we have isolated and characterized nine undescribed derivatives, amycolataiwanensins A-J from an actinobacteria strain Amycolatopsis taiwanensis that was isolated from soilt of Yilan township, in the north of Taiwan. The relative configurations of new isolates were determined by comparing their optical activities with related derivatives and NOESY plots. Amycolataiwanensins C, E, H \& I showed inhibitory activities against LPS-induced NO production in RAW 264.7.

The discovery of indole, sesquiterpenes, diterpenes, and chromenes derivatives from actinobacteria pointed toward the potential of endophytic or associated Amycolatopsis taiwanensis as alternative producer of indole, sesquiterpenes, diterpenes, and chromenes derivatives. The current results may encourage further investigations on the chemistry and bioactivity of flavan metabolites. These results also suggest that Amycolatopsis has distinct and diverse metabolites that arise under different fermentation conditions and soil-derived collections. It may therefore be possible to find more new bioactive natural products by searching Amycolatopsis species under special eco-environment. For the sake of better understanding the distribution of flavan acid analogs, the actinobacteria of the tilted research material and other special strains are worth examining for the presence of these secondary metabolites.

Supplementary Materials: The following are available online at https://www.mdpi.com/article/ 10.3390/molecules26195765/s1. Figure S1: ${ }^{1} \mathrm{H}$ NMR spectrum of 1; Figure S2. ${ }^{13} \mathrm{C}$ NMR spectrum of 1; Figure S3: ${ }^{1} \mathrm{H}^{-1} \mathrm{H}$ COSY spectrum of 1 ; Figure S4: HMBC spectrum of 1; Figure S5: NOESY spectrum of 1; Figure S6: HSQC spectrum of 1; Figure S7: EI-MS spectrum of 1; Figure S8: ${ }^{1} \mathrm{H}$ NMR spectrum of 2; Figure S9: ${ }^{13} \mathrm{C}$ NMR spectrum of 2; Figure S10: ${ }^{1} \mathrm{H}-{ }^{1} \mathrm{H}$ COSY spectrum of 2; Figure S11: HMBC spectrum of 2; Figure S12: NOESY spectrum of 2; Figure S13: HSQC spectrum of 2; Figure S14: EI-MS spectrum of 2; Figure S15: ${ }^{1} \mathrm{H}$ NMR spectrum of 3; Figure S16: ${ }^{13} \mathrm{C}$ NMR spectrum of 3; Figure S17: ${ }^{1} \mathrm{H}^{-1} \mathrm{H}$ COSY spectrum of 3; Figure S18: HMBC spectrum of 3; Figure S19: NOESY spectrum of 3; Figure S20: HSQC spectrum of 3; Figure S21: EI-MS spectrum of 3; Figure S22: ${ }^{1} \mathrm{H}$ NMR spectrum of 4; Figure S23: ${ }^{13} \mathrm{C}$ NMR spectrum of 4; Figure S24: ${ }^{1} \mathrm{H}-$ ${ }^{1} \mathrm{H}$ COSY spectrum of 4; Figure S25: HMBC spectrum of 4; Figure S26: NOESY spectrum of 4; Figure S27: HSQC spectrum of 4; Figure S28: EI-MS spectrum of 4; Figure S29: ${ }^{1} \mathrm{H}$ NMR spectrum of 5; Figure S30: ${ }^{13} \mathrm{C}$ NMR spectrum of 5; Figure S31: ${ }^{1} \mathrm{H}-{ }^{1} \mathrm{H}$ COSY spectrum of 5; Figure S32: HMBC spectrum of 5; Figure S33: NOESY spectrum of 5; Figure S34: HSQC spectrum of 5; Figure S35: EI-MS spectrum of 5; Figure S36: ${ }^{1} \mathrm{H}$ NMR spectrum of 6; Figure S37: ${ }^{13} \mathrm{C}$ NMR/DEPT spectra of 6; Figure S38: ${ }^{1} \mathrm{H}-{ }^{1} \mathrm{H}$ COSY spectrum of 6; Figure S39: HMBC spectrum of 6; Figure S40: NOESY spectrum of 6; Figure S41: HSQC spectrum of 6; Figure S42: EI-MS spectrum of 6; Figure S43: ${ }^{1} \mathrm{H}$ NMR spectrum of 7; Figure S44: ${ }^{13} \mathrm{C}$ NMR/DEPT spectra of 7; Figure S45: ${ }^{1} \mathrm{H}-{ }^{1} \mathrm{H}$ COSY spectrum of 7; Figure S46: HMBC spectrum of 7; Figure S47: NOESY spectrum of 7; Figure S48: HSQC spectrum of 7; Figure S49: EI-MS spectrum of 7; Figure S50: ${ }^{1} \mathrm{H}$ NMR spectrum of 8; Figure S51: ${ }^{13} \mathrm{C}$ NMR/DEPT spectra of 8; Figure S52: ${ }^{1} \mathrm{H}^{-1} \mathrm{H}$ COSY spectrum of 8; Figure S53: HMBC spectrum of 8; Figure S54: NOESY spectrum of 8; Figure S55: HSQC spectrum of 8; Figure S56: EI-MS spectrum of 8; Figure S57: ${ }^{1} \mathrm{H}$ NMR spectrum of 9; Figure S58: ${ }^{13} \mathrm{C}$ NMR/DEPT spectra of 9; Figure S59: ${ }^{1} \mathrm{H}-$ ${ }^{1} \mathrm{H}$ COSY spectrum of 9; Figure S60: HMBC spectrum of 9; Figure S61: NOESY spectrum of 9; Figure S62: HSQC spectrum of 9; Figure S63: EI-MS spectrum of 9; Figure S64: ${ }^{1} \mathrm{H}$ NMR spectrum of 10; Figure S65: ${ }^{13} \mathrm{C}$ NMR/DEPT spectra of 10; Figure S66: ${ }^{1} \mathrm{H}^{-}{ }^{1} \mathrm{H}$ COSY spectrum of 10; Figure S67: HMBC spectrum of 10; Figure S68: NOESY spectrum of 10; Figure S69: HSQC spectrum of 10; Figure S70: EI-MS spectrum of 10.

Author Contributions: A.-L.K., C.-Y.C. and M.-J.C. designed the research; Y.-S.S. and M.-J.C. performed the research; Y.-S.S. conducted biological assays, Y.-S.S., M.-D.W.W, J.-J.C., Y.-H.K. and M.-J.C. helped with structure elucidation, Y.-S.S. and M.-J.C. analyzed the data and wrote the paper. All authors have read and agreed to the published version of the manuscript.

Funding: This work was partial kindly supported by the Food Industry Research and Development Institute (FIRDI) and supported by Ministry of Science and Technology, R.O.C. (MOST-108-2320B-080-002- \& 110-2320-B-080-001-) This work was partial financially supported by China Medical 
University grant in Taiwan (CMU110-Z-08 and CMU109-AWARD-02) and "Chinese Medicine Research Center, China Medical University" from The Featured Areas Research Center Program within the framework of the Higher Education Sprout Project by the Ministry of Education (MOE) in Taiwan (CMRC-CHM-2-1).

Institutional Review Board Statement: Not applicable.

Informed Consent Statement: Not applicable.

Data Availability Statement: The data presented in this study are available in article and Supplementary Material.

Acknowledgments: The authors thank Min Tseng for her help in strain identification, cultivation and fermentation and also thank Senior Technician Chyi Jia Wang of Center for Resources, Research and Development (CRRD) of Kaohsiung Medical University for measuring the 2D NMR data.

Conflicts of Interest: The authors declare no conflict of interest.

\section{References}

1. Osada, H. Fascinating bioactive compounds from actinomycetes. Actinomycetologica 1995, 9, 254-262. [CrossRef]

2. Mythili, B.; Ayyappa Das, M.P. Studies on antimicrobial activity of Streptomyces spp. isolates from tea plantation soil. Res. J. Agric. Sci. 2011, 2, 104-106.

3. Kuster, E. The Actinomycetes. In Soil Biology; Burges, A., Raw, F., Eds.; Academic Press: London, UK, 1968 ; pp. 111-124.

4. Butler, M.S. The role of natural product chemistry in drug discovery. J. Nat. Prod. 2004, 67, 2141-2153. [CrossRef]

5. Tseng, M.; Yang, S.F.; Li, W.J.; Jiang, C.L. Amycolatopsis taiwanensis sp. nov., from soil. Int. J. Syst. Evol. Microbiol. 2006, 56, 1811-1815. [CrossRef]

6. Song, Z.; Xu, T.; Wang, J.; Hou, Y.; Liu, C.; Liu, S.; Wu, S. Secondary Metabolites of the Genus Amycolatopsis: Structures, Bioactivities and Biosynthesis. Molecules 2021, 26, 188. [CrossRef]

7. Nakajima, E.; Nakano, H.; Yamada, K.; Shigemori, H.; Hasegawa, K. Isolation and identification of lateral bud growth inhibitor, indole-3-aldehyde, involved in apical dominance of pea seedlings. Phytochemistry 2002, 61, 863-865. [CrossRef]

8. Evidente, A.; Motta, A.; Sparapano, L. Seiricardines B and C, phytotoxic sesquiterpenes from three species of Seiridium pathogenic for cypress. Phytochemistry 1993, 33, 69-78. [CrossRef]

9. Ke, L.Y.; Zhang, Y.; Xia, M.Y.; Zhuo, J.X.; Wang, Y.H.; Long, C.L. Modified Abietane Diterpenoids from Whole Plants of Selaginella moellendorffii. J. Nat. Prod. 2018, 23, 418-422. [CrossRef]

10. Sitarek, P.; Toma, M.; Ntungwe, E.; Kowalczyk, T.; Skała, E.; Wieczfinska, J.; Śliwiński, T.; Rijo, P. Insight the Biological Activities of Selected Abietane Diterpenes Isolated from Plectranthus spp. Biomolecules 2020, 10, 194. [CrossRef]

11. Ohtsu, H.; Tanaka, R.; Matsunaga, S. Abietane diterpenoids from the cones of larix kaempferi. J. Nat. Prod. 1998, 61, 1307-1309. [CrossRef] [PubMed]

12. Wheeler, D.M.S.; Witt, P.R. Witt Conversion of podocarpic acid to an 18-nor steroid. J. Org. Chem. 1972, 37, 4211-4214. [CrossRef] [PubMed]

13. Rustaiyan, A.; Saberi, M.; Habibi, Z.; Jakupovic, J. Melampolides and other constituents from Furinea leptoloba. Phytochemistry 1991, 30, 1929-1932. [CrossRef]

14. Wu, X.; Ke, C.Q.; Yang, Y.P.; Ye, Y. New biphenyl constituents from Garcinia oblongifolia. Helvetica Chim. Acta 2008, 91, 938-943. [CrossRef]

15. Stork, G.; Clarke, F.H., Jr. Cedrol: Stereochemistry and Total Synthesis. J. Am. Chem. Soc. 1961, 83, 3114-3125. [CrossRef]

16. Gieni, R.S.; Li, Y.; Hay Glass, K.T. Comparison of [3H]thymidine incorporation with MTT- and MTS-based bioassays for human and murine IL-2 and IL-4 analysis. Tetrazolium assays provide markedly enhanced sensitivity. J. Immunol. Methods 1995, 70, 85-93. [CrossRef]

17. Johansson, M.; Kopcke, B.; Anke, H.; Sterner, O. Biologically active secondary metabolites from the ascomycete A111-95. 2. Structure elucidation. J. Antibiot. 2002, 55, 104-106. [CrossRef] [PubMed]

18. Cheng, M.J.; Wu, M.D.; Chan, H.Y.; Chang, H.S.; Wu, H.C.; Chen, J.J.; Yuan, G.F.; Weng, J.R.; Chang, C.T.; Lin, H.C. A new azaphilone derivative from the Monascus kaoliang fermented rice. Chem. Nat. Compd. 2019, 55, 79-81. [CrossRef]

19. Wu, H.C.; Cheng, M.J.; Wu, M.D.; Chen, J.J.; Chen, Y.L.; Chang, H.S. Three new constituents from the fungus of Monascus purpureus and their anti-inflammatory activity. Phytochem. Lett. 2019, 31, 242-248. [CrossRef]

20. Cheng, M.J.; Wu, M.D.; Su, Y.S.; Chan, H.Y.; Hsieh, S.Y.; Chen, Y.L.; Chen, J.J.; Chou, Y.T.; Hsiao, C.Y.; Wu, H.S. Additional Chemical Constituents of an Endophytic Fungus Xylaria papulis. Chem. Nat. Compd. 2019, 55, 340-342. [CrossRef]

21. Feng, K.J.; Cheng, M.J.; Yang, S.H.; Wu, M.D.; Hsieh, S.Y.; Chan, H.Y.; Su, Y.S.; Chou, Y.T.; Chang, H.S. Chemical Constituents of the Endophytic Fungus Ophiocordyceps sobolifera. Chem. Nat. Compd. 2019, 55, 309-312. [CrossRef] 
22. Cheng, M.J.; Wu, M.D.; Wu, H.C.; Chan, H.Y.; Chen, Y.L.; Chang, H.S.; Chen, J.J.; Kuo, Y.H. Benzenoid Derivatives and Amide Constituents of the Monascus sp.-Fermented Rice. Chem. Nat. Compd. 2019, 55, 787-789. [CrossRef]

23. Wu, H.C.; Chen, J.J.; Wu, M.D.; Cheng, M.J.; Chang, H.S. Identification of new pigments produced by the fermented rice of the fungus Monascus pilosus and their anti-inflammatoryactivity. Phytochem. Lett. 2020, 40, 181-187. [CrossRef] 